\title{
A multi-oscillatory circadian system times female reproduction
}

\author{
Valérie Simonneaux ${ }^{1 \star}$ and Thibault Bahougne ${ }^{1,2}$ \\ ${ }^{1}$ Institut des Neurosciences Cellulaires et Intégratives, CNRS (UPR 3212), Strasbourg, France, ${ }^{2}$ Service d'Endocrinologie et \\ Diabète, Hôpital Civil, Hôpitaux Universitaires de Strasbourg, Strasbourg, France
}

Rhythms in female reproduction are critical to insure that timing of ovulation coincides with oocyte maturation and optimal sexual arousal. This fine tuning of female reproduction involves both the estradiol feedback as an indicator of oocyte maturation, and the master circadian clock of the suprachiasmatic nuclei (SCN) as an indicator of the time of the day. Herein, we are providing an overview of the state of knowledge regarding the differential inhibitory and stimulatory effects of estradiol at different stages of the reproductive axis, and the mechanisms through which the two main neurotransmitters of the SCN, arginine vasopressin, and vasoactive intestinal peptide, convey daily time cues to the reproductive axis. In addition, we will report the most recent findings on the putative

OPEN ACCESS

Edited by: Hubert Vaudry, University of Rouen, France

Reviewed by: Yoshitaka Oka University of Tokyo, Japan Vance Trudeau, University of Ottawa, Canada

${ }^{*}$ Correspondence:

Valérie Simonneaux, Institut des Neurosciences Cellulaires et Intégratives, CNRS (UPR 3212),

5 rue Blaise Pascal,

Strasbourg 67084, France simonneaux@inci-cnrs.unistra.fr

Specialty section:

This article was submitted to Neuroendocrine Science, a section of the

journal Frontiers in Endocrinology

Received: 14 June 2015 Accepted: 21 September 2015 Published: 20 October 2015

Citation:

Simonneaux $V$ and Bahougne $T$ (2015) A multi-oscillatory circadian system times female reproduction.

Front. Endocrinol. 6:157. doi: 10.3389/fendo.2015.00157 functions of peripheral clocks located throughout the reproductive axis [kisspeptin (Kp) neurons, gonadotropin-releasing hormone neurons, gonadotropic cells, the ovary, and the uterus]. This review will point to the critical position of the Kp neurons of the anteroventral periventricular nucleus, which integrate both the stimulatory estradiol signal, and the daily arginine vasopressinergic signal, while displaying a circadian clock. Finally, given the critical role of the light/dark cycle in the synchronization of female reproduction, we will discuss the impact of circadian disruptions observed during shift-work conditions on female reproductive performance and fertility in both animal model and humans.

Keywords: female reproduction, circadian clock, suprachiasmatic nuclei, kisspeptin, GnRH, LH, estradiol, shift-work

\section{Introduction}

Ovulation in female mammals is a complex process, which is exquisitely regulated by a number of environmental (time of day, time of year, food resources, and stress level) and internal (development stage, hormonal milieu, and metabolic rate) factors. Indeed, female reproduction is a long-term, demanding process and therefore, it is important that a limiting critical status is reached to ensure successful reproductive outcome. In adult females where all these criteria are attained, there are still two important cues that time ovulation: the circulating level of gonadal hormones, specifically estradiol, which is an indicator of oocyte maturation, and the time of day arising from biological clocks. This dual regulation ensures that the timing of ovulation coincides with the period of maximal activity and sexual motivation. Most mechanistic studies aimed at understanding this subtle timing of ovulation have been performed in laboratory rodents, but ovulation in humans is also gated by similar hormonal and circadian inputs. Hence, this review will not only focus on the mechanisms regulating the timing of reproduction in female rodents, but will also discuss human female fertility, including the desynchronization associated with modern life styles (shift work, jet lag, and sleep alteration). 


\section{Female Reproduction is Rhythmic}

Reproductive activity in female mammals displays a regular cycle (menstrual cycles in women, estrous cycles in rodents) driven by a complex interaction of the circadian system, hypothalamic neuropeptides, gonadotropins [luteinizing hormone (LH) and follicle-stimulating hormone (FSH), both secreted by the pituitary gonadotroph cells], and sex steroid hormones produced by the ovaries. The final output of this regulatory process is to combine the production of a mature oocyte (ovulation) with a receptive reproductive tract, which will ensure the embryo's development.

During the first part of the reproductive cycle (follicular phase in women; metestrus-diestrus in rodents), gonadotrophs produce more FSH than $\mathrm{LH}$. This relative FSH preponderance contributes to the recruitment and development of ovarian follicles. FSH promotes follicular growth leading to a progressive increase of the sex steroid hormone, estradiol, and increases LH receptor expression in granulosa cells (1). During this early phase, LH pulses occur with a high frequency (period of 1-2 $\mathrm{h}$ in women, $20 \mathrm{~min}$ in rodents) and uniform amplitude, and the pulse frequency tends to increase toward the end of the phase. The second part of the reproductive cycle (luteal phase in women; proestrus-estrus in rodents) begins with a marked and transient secretion of $\mathrm{LH}$ (Figures 1A,D). The LH surge has three functions: (1) induction of ovulation of mature follicles, (2) resumption of oocyte meiosis, and (3) arrest of granulosa cell proliferation and luteum induction. After the LH surge, ovulation generally follows a few hours later in rodents, and $24-48 \mathrm{~h}$ in women. The preovulatory LH surge takes place approximately every 4-5 days in rodents and every 28 days in women and its occurrence depends on high circulating estradiol levels $(2,3)$. Additionally, the LH surge requires a daily signal since it arises at a very specific time of day, usually at the end of the resting period, thus in the late afternoon in nocturnal rodents and the end of the night/early morning in the diurnal rodent Arvicanthis (4) and in humans (5-7). Indeed, in $80 \%$ of women, the LH surge occurs around 8 a.m. At the end of the reproductive cycle, $\mathrm{LH}$ pulse frequency decreases significantly down to a pulse interval of 2-6 h with variable amplitude (8).

The secretion of both $\mathrm{LH}$ and FSH is under the control of a hypothalamic neurohormone, gonadotropin-releasing hormone $(\mathrm{GnRH})$, which is synthesized in neurons scattered throughout the preoptic area (POA) and the organum vasculosum laminae terminalis. These neurons project to the median eminence where they release $\mathrm{GnRH}$ in the portal circulation in a pulsatile manner. GnRH activates specific receptors located on pituitary gonadotrophs inducing the synthesis and release of LH and FSH. GnRH is essential for reproduction as mutations in the gene coding for $\mathrm{GnRH}$ (10) and GnRH receptor (11) are proposed to be responsible for idiopathic hypogonadotropic hypogonadism (IHH), characterized by delayed puberty and infertility (11). The pulsatility of $\mathrm{GnRH}$ release is critical to induce proper gonadotropin secretion, and there is a tight correlation between $\mathrm{GnRH}$ and $\mathrm{LH}$ pulsatilities. Pulsatile administration of exogenous $\mathrm{GnRH}$ (one pulse per hour) is capable of restoring the preovulatory surge, ovulation, and normal menstrual cycles in patients suffering from Kallmann syndrome $(12,13)$. In contrast, continuous GnRH administration induces a reversible blockage of the pituitary gonadotroph cells' secretion (14).

Various (neuro)transmitters had been proposed to regulate $\mathrm{GnRH}$ neuronal activity until the neuropeptide kisspeptin (Kp) was discovered as a potent activator of GnRH release. In 1996, the Kiss 1 gene was discovered and reported to encode a peptide called metastin, because of its anti-metastatic property on malignant melanoma cells (15). However, the receptor of this peptide, GPR54, was later found to play a critical role in reproductive physiology when two groups reported that mutation of the GPR54 receptor results in $\mathrm{IHH}$ in humans, with an identical phenotype observed in mice with a targeted deletion in this receptor $(16,17)$. The Kiss 1 gene was shown to encode a family of Kps from an initial 145 amino acid propeptide, Kp-145, which is cleaved into peptides of different sizes from Kp-54 (previously named metastin) to Kp-10. The discovery of Kp's role in reproductive function has been a milestone in the field of reproductive biology, and numerous studies now indicate that Kps are critical regulators of sexual differentiation and maturation as well as of normal adult reproductive functioning across mammalian species, including humans (18). Kp neurons are localized within two hypothalamic areas, in the arcuate nucleus (ARN) and the rostral periventricular nucleus of the third ventricle, also called anteroventral periventricular nucleus (AVPV), or the preotic area (according to species). They send projections mainly to the GnRH neuron cell bodies (AVPV Kp neurons) and nerve terminals [ARN Kp neurons (19-22)] (Figure 1A). The AVPV presents a marked sexual dimorphism, with more Kp neurons in females as compared to males $(20,23)$. The AVPV Kp neurons are the main drivers of the preovulatory GnRH/LH surge (24). In contrast, the ARN Kp neurons are not sexually dimorphic $(20,23)$. The Kp receptor, Kiss1R (formerly GPR54), is highly expressed in GnRH neurons but also in other brain areas $(25,26)$ and in most endocrine tissues like the pituitary gland, ovary, and placenta (27). Kp has a very potent stimulatory action on $\mathrm{GnRH}$ release and, therefore, gonadotropin secretion in all mammalian species investigated so far $(18,19,28,29)$. Central injection of doses as low as $0.1-1 \mathrm{pmol} \mathrm{Kp} 10$ is indeed sufficient to evoke robust $\mathrm{LH}$ secretion in rats and monkeys $(28,30) \mathrm{Kp}$ injections must be short and at least $2 \mathrm{~h}$ apart to induce the $\mathrm{LH}$ peak since the repeated administration of $\mathrm{Kp}$ induces Kiss1R desensitization $(31,32)$. Notably, Kp release in the stalk-median eminence is pulsatile (33), and pulsatile Kp drives $\mathrm{LH}$ secretion in juvenile monkeys (34). A recent study reported that pulsatile administration of $\mathrm{Kp}$ was able to evoke dramatic synchronous activation of $G n R H$ gene transcription with robust stimulation of GnRH secretion in murine-cultured hypothalamic explants (35). The preeminent phenotypes of impaired reproduction (abnormal sexual maturation, small uterus, ovaries without mature follicles, no estrous cycles) often arise from mutations in $\operatorname{Kiss} 1(36,37)$ and Kiss1R $(16,38,39)$, which suggest that the Kiss1/Kiss1R complex is essential for the central regulation of the gonadotropic axis.

Other classical neurotransmitters and neuropeptides have been reported to regulate $\mathrm{GnRH}$ neuron activity albeit not to the same extent as Kp. GABA and glutamate fibers are found close to GnRH perikarya in the POA and axons in the median eminence. Both neurotransmitters have been shown to play a role in the regulation of $\mathrm{GnRH}$ release. Glutamate stimulates Gnrh gene 


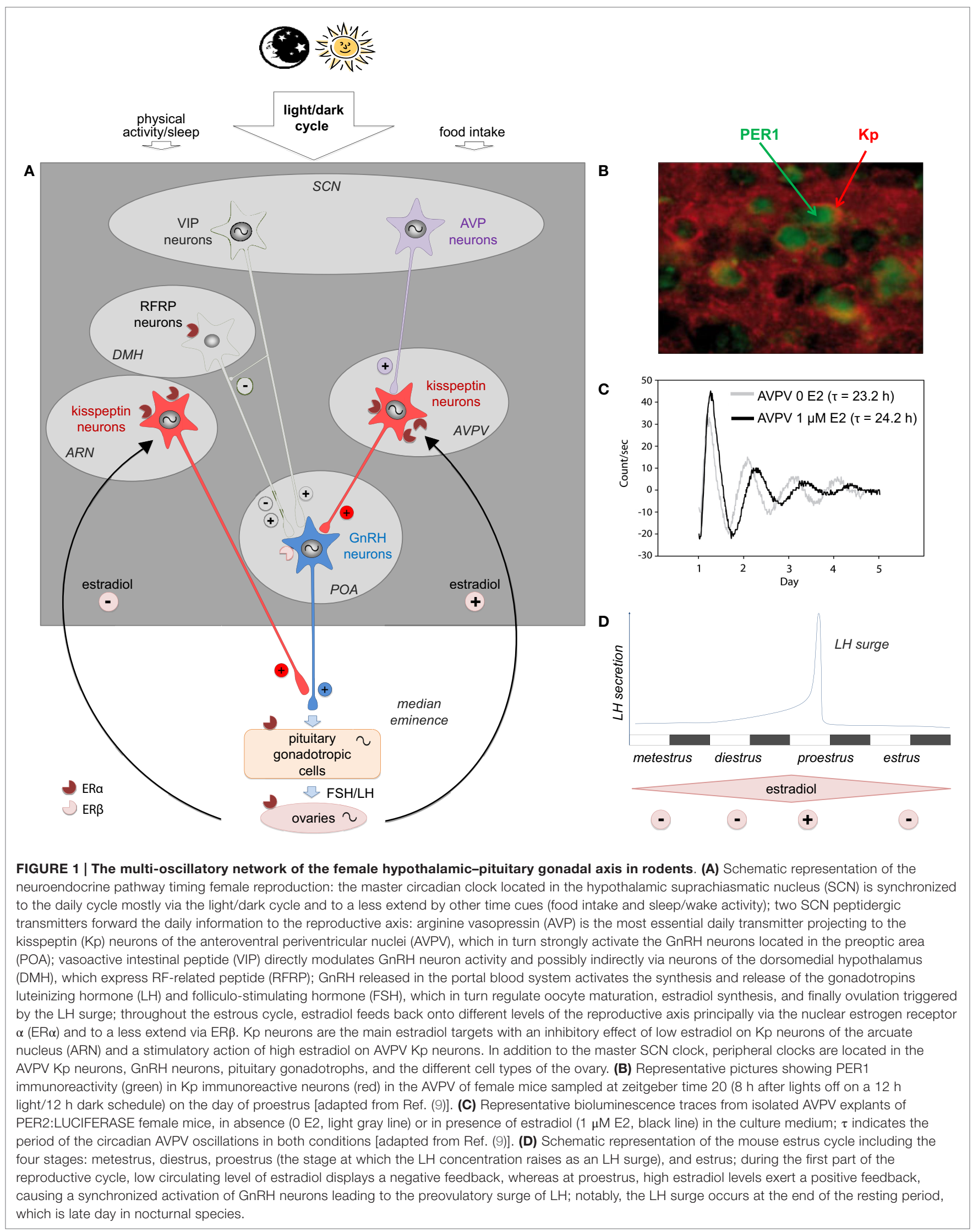


expression and GnRH release during the LH surge, whereas a glutamate antagonist blocks Gnrh gene expression and the LH surge when administered in the morning (40-42). Administration of an AMPA agonist enhances the in vivo LH secretion in OVX rats only with estradiol substitution, whereas glutamate stimulates in vitro $\mathrm{GnRH}$ secretion in a estradiol-independent matter (43). The role of GABA on GnRH neuronal activity is debated since inhibitory and stimulatory effects have been observed depending on the protocols used, the presence of sex steroid treatment, the timing in the estrus cycle and the hypothalamic region studied $(44,45)$. Fibers containing the orexigenic neuropeptide $Y$ contact a majority of $\mathrm{GnRH}$ neurons, which express neuropeptide Y receptors. This neuropeptide has been reported to exert variable effects depending on the metabolic and reproductive status of the animal, but most of the studies describe an inhibitory effect of neuropeptide Y on GnRH neurons (46-48). Recent studies indicate that another neuropeptide belonging to the same RF-amide peptide family as Kp, RFRP-3 (the mammalian homolog of avian gonadotropin-inhibitory hormone), regulates $\mathrm{GnRH}$ neuron activity [for review, see Ref. (49-51)]. Unlike Kp, RFRP-3 can activate or inhibit the reproductive axis according to gender, species, and environmental conditions $(26,51-53)$. In female rodents RFRP neuronal activity is decreased at the time of the LH surge, possibly to relieve the inhibitory effect of RFRP-3 on GnRH neurons (54). However, mice bearing a null mutation of GPR147, the RFRP-3 receptor, present only a mild reproductive phenotype (55).

\section{Estrogenic Regulation}

Estradiol produced by the ovaries exerts both positive and negative feedback upstream of the reproductive axis, modulating GnRH neuron activity and anterior pituitary gonadotroph cells. During the first part of the reproductive cycle, estradiol induces a negative feedback, whereas when estradiol concentration is the highest (at the end of the follicular phase in humans or proestrus in rodents) the feedback becomes positive, causing a synchronized activation of GnRH neurons leading to $\mathrm{GnRH}$ release in the hypophyseal portal blood and finally the preovulatory $\mathrm{LH}$ surge (56) (Figures 1A,D). The effect of estradiol is mediated via two types of nuclear estrogen receptors (ERs), which induce long lasting genomic action, $\operatorname{ER} \alpha$ and $\operatorname{ER} \beta(57,58)$, but it can also have a rapid action via membrane bound estradiol receptors, including the GPR30 $(59,60)$.

\section{GnRH Neurons}

Gonadotropin-releasing hormone neurons contain few, if any, ER $\alpha$ (61-63), but do express ER $\beta$ (64-66) and GPR30 (67). Estradiol application to cultured primate $\mathrm{GnRH}$ neurons induces a rapid increase in action potential firing frequency (68) and intracellular calcium oscillations (69). Similar effects have been reported in the mouse GnRH neurons (70). This rapid effect of estradiol is proposed to be mediated via GPR30 in primates (67) and ER $\beta$ in mice $(70,71)$. Using an in vitro GnRH neuronal model, the GT1-7 cells, it was reported that Kiss $1 R$ expression is estradiol dependant, with a Kp-induced GnRH increase only in cells treated with estradiol $(72,73)$. A primary effect of estradiol on GnRH neurons has been hypothesized to upregulate expression of channel transcripts (TRPC4 channels and HCN1 channels) that orchestrate the downstream signaling of Kiss1R in GnRH neurons $(74,75)$. Therefore, estradiol could be a potent regulator of ion channel and receptor expression in GnRH cells, hence controlling the sensitivity of GnRH neurons to Kp. However, a recent study reported that mutant mice with a GnRH neuron-selective deletion of ER $\beta$ exhibit normal cycles and negative feedback, leaving the critical role for ER $\beta$ in GnRH neuron activity still an open question (76).

\section{Kisspeptin Neurons}

In contrast to $\mathrm{GnRH}, \mathrm{Kp}$ neurons have a high density of ER $\alpha$ and are, therefore, considered as the intermediate node for the estradiol feedback on GnRH neurons (19, 20, 32, 61, 77-79) (Figure 1A). Interestingly, the estradiol feedback in rodents depends on the Kp neuron localization as estradiol stimulates Kiss 1 expression in the AVPV and inhibits Kiss 1 expression in the ARN (77, 80-82). In non-rodent mammals, a similar differential regulation by estradiol is also observed with a stimulatory effect in the rostral periventricular/POA and an inhibitory effect in the ARN $(83,84)$. The mechanism underlying these differences in the regulation of Kiss 1 expression by $\mathrm{ER} \alpha$ in both structures is not yet fully understood. AVPV Kiss1 activation requires an estrogen response element (ERE)-dependent pathway, whereas inhibition of Kiss 1 expression in the ARN involves ERE-independent mechanisms $(80,85)$. Recent studies have reported that estradiol additionally modulates daily activity of AVPV Kp neurons. Hence, the daily variation in c-Fos activation, Kiss 1 mRNA and peptide content observed in proestrus or in ovariectomized estradioltreated rodents is abolished or strongly reduced in diestrus or in ovariectomized animals (9, 86-88). Furthermore, estradiol has been reported to increase the number of arginine vasopressin (AVP) synaptic contacts onto Kp neurons (89), regulate $\mathrm{AVP}_{1 a}$ receptor expression by Kp neurons (88) and be permissive for the AVP-induced electrical activation of Kp neurons (90). Altogether these observations indicate that high circulating levels of estradiol gate the action of AVP onto AVPV Kp neurons (see Role of the Suprachiasmatic Nuclei for the role of AVPV on Kp neurons).

\section{Circadian System}

Estradiol is also suggested to influence daily functions since shifts are observed during the pubertal period, pregnancy, menopause, and throughout the reproductive cycle (91-93). In rodents, ER $\alpha$ and $\operatorname{ER} \beta$ are expressed in the retina, the retino-hypothalamic tract, the geniculohypothalamic tract and raphe nuclei-derived serotonergic inputs, all major inputs to the suprachiasmatic nuclei (SCN), which contain the master circadian clock (94). In mice, the second half of the proestrus night is often, but not consistently, characterized by increased motor activity compared to the remaining nights of the estrous cycle $(95,96)$. Furthermore, ovariectomy reduces total motor activity, and estradiol reverses this effect, while also shortening the length of the free running period and advancing the onset of wheel running activity (96). Estradiol may act directly on SCN clock gene oscillation since estradiol treatment in ovariectomized rats decreased Cry 2 mRNA levels (97) and estradiol application to SCN slices increased the spontaneous firing frequency and depolarized cell membranes 
of the SCN neurons (98). However, other studies reported that estradiol treatment of SCN explants from PER2:LUCIFERASE mice has no effect on the period and amplitude of the circadian oscillations (9, 99). Alternatively, estradiol may alter rhythms in running activity via indirect effects on the medial POA or striatum $(100,101)$.

\section{Pituitary}

Pituitary gonadotrophs express $\mathrm{ER} \alpha$, and estradiol has been proposed to exert a direct negative feedback effect on gonadotropin secretion (102-104). Chronic treatment with estradiol induces negative feedback effects on gonadotrophin secretion after $\mathrm{GnRH}$ supraphysiologic stimulation in ewes (105) or humans (106). Interestingly, a recent study reported that mice with a selective deletion of ER $\alpha$ in pituitary gonadotroph cells had elevated serum LH and estradiol values, and displayed irregular estrous cycles punctuated by prolonged periods of disorganized cycling, pointing to $\mathrm{ER} \alpha$ participation in the estradiol negative feedback at the pituitary level (107). It is worth mentioning that this phenotype was much less severe than the one observed after a total ER $\alpha$ deletion. Although the role of Kiss/Kiss1R at the pituitary is still the subject of debate, it is interesting to note that the activation of pituitary ER $\alpha$ up-regulates Kiss 1 expression, whereas chronic exposure to estradiol down regulates Kiss $1 R$ expression on pituitary gonadotrophs (108).

\section{Uterus}

The uterus expresses high levels of $\mathrm{ER} \alpha$, and is an important site for the estrogenic control of reproductive physiology $(109,110)$. Estradiol, together with progesterone, regulates uterine growth and differentiation, which in turn control embryo-endometrial interactions during early pregnancy (110). Furthermore, estradiol treatment also shortens the period of the circadian clock in the uterus (99).

\section{Daily and Circadian Regulations}

\section{Role of the Suprachiasmatic Nuclei The Hypothalamic Suprachiasmatic Nuclei Host the Master Biological Clock}

Most biological functions, including female reproduction, are synchronized to the daily variation of environmental factors. Among these factors, the recurring light/dark cycle is the most predictable environmental cue used by mammals to adjust their behavior and physiology appropriately. The mechanisms by which light and dark synchronize biological functions involve the master biological clock located in the hypothalamic SCN and a retino-hypothalamic tract, which forwards the non-visual light to the SCN.

The demonstration that a biological clock located in the basal hypothalamus was driving circadian rhythms came from experiments showing that SCN lesions in rodents abolished circadian rhythms in locomotor activity, which were restored following exogenous SCN implants $(111,112)$. The circadian activity of SCN neurons relies on a complex molecular system cycling endogenously with a period of about 1 day (circa dies). This molecular clockwork is composed of transcription-translation loops, which are now well described $(113,114)$. Dimers of the CLOCK and BMAL1 proteins bind to a specific E-box promoter to induce the transcription of four clock genes Per1, Per2, Cry1, and $C r y 2$, which after translation produce proteins which form dimers to repress their own transcription by competing with the CLOCK/BMAL1 binding. Following degradation of the inhibitory proteins, the transcription-translation loop starts over for another circadian cycle. When SCN explants or dissociated cells are kept in vitro, the endogenous circadian oscillations continue for weeks or months, providing that the culture medium gets enough nutrients and oxygen for the cell metabolism. A very interesting animal model used to demonstrate these sustained endogenous oscillations is the PER2:LUCIFERASE mice, where the expression of the luciferase gene is driven by the Per2 promoter (115, 116). When explants or dissociated cells of PER2:LUCIFERASE mouse SCN are placed in a culture medium containing luciferine, the rhythmic expression of PER2 drives a rhythmic expression of luciferase, which by oxidizing luciferin causes the emission of a bioluminescent signal with a circadian period.

In order to achieve its role in adjusting biological functions with the astronomical daily cycles, the SCN circadian activity has to be synchronized with the time of day and transmit this timing information to the rest of the body. Light has long been known to be the main synchronizer of the SCN circadian clock, but interestingly it uses a specific non-visual pathway, which includes melanopsin-containing intrinsically photosensitive retinal ganglion cells projecting directly to the SCN $(117,118)$. Upon light activation, these ganglion cell terminals release glutamate and pituitary activating cAMP peptide, which change the phase (synchronizes) of the circadian clock. The synchronizing property of light depends on the time of application during the day, and the characteristics of the phase responses depend on species. The astronomical light/dark alternation synchronizes the circadian clock in order to attain a daily rhythm of a precise 24 -h period. The CLOCK/BMAL1 dimers not only activate canonical clock gene expression, but other clock-controlled genes whose promoters display E-boxes and therefore undergo rhythmic expression. This mechanism was first demonstrated for the gene encoding AVP, an important output of the SCN clock (119). Levels of SCN AVP mRNA are markedly higher during the day than at night, but in Clock KO mice the SCN AVP rhythm is strongly dampened (120).

\section{SCN Lesion or Clock Gene Mutations Alter the Reproductive Cycle}

Various experiments aiming at impairing clock function were performed to delineate whether functional SCN neurons are required for the daily timing of the $\mathrm{LH}$ surge, mostly in female rodents. Early experiments of SCN lesions (121) or SCN-POA neuronal connection cut (122) resulted in an impaired $\mathrm{LH}$ surge and estrous cyclicity in female rats. Furthermore, female mice carrying mutations of Clock or Bmal1 displayed disrupted estrous cycles (123-127). Clock $^{-/-}$mutant mice, for example, have extended and disrupted estrous cycles under both a light/ dark cycle and during continuous darkness. In humans, it was reported that women with single-nucleotide polymorphisms in the ARNTL (Bmal1) have more miscarriages and less 
pregnancies than those without (128). Although these experiments have pointed to a crucial role of the SCN in the proper timing of estrous cyclicity, reproductive impairment following clock gene mutations could as well result from peripheral clock desynchronization (see Other Clocks in the Reproductive System). Interestingly, the reproductive phenotypes of young Clock-, Bmal1-, or Per1/Per2-mutated mice resemble that of middle-aged (over 10-month old) wild-type mice, with increased length and decreased frequency of estrous cycles (129, 130). These observations indicate that alterations in central or peripheral clocks may lead to advanced reproductive senescence (130).

The preovulatory LH surge is initiated by a SCN-derived stimulatory signal, at a time closely preceding general activity onset. However, this signal is effective at stimulating GnRH neurons to produce the LH surge only when estradiol concentrations have reached a critical threshold. Prior to the day of proestrus, the developing ovarian follicles secrete insufficient estradiol to fulfill this criteria and therefore, the SCN signal does not trigger the LH surge (56). The occurrence of the daily stimulatory SCN signal can be unmasked by implanting female rodents with estradiol capsules that result in proestrus concentrations of this hormone; in this case, a LH surge occurs every day $(3,56,131)$.

\section{SCN Neuropeptides Involved in the Timing of the GnRH/LH Surge}

Transplant of fetal SCN tissue into bilaterally SCN-lesioned hamsters restores locomotor, but not endocrine rhythms in the absence of neural outgrowth, suggesting that intact neural connections are required for endocrine rhythmicity, whereas behavioral rhythms can be supported by a diffusible signal (132). Neuroanatomical studies have pointed to two putative SCN neural outputs signaling daily information to the reproductive axis, AVP and vasoactive intestinal peptide (VIP). Early experiments have identified SCN-originating, VIP-containing fibers contacting GnRH neurons $(133,134)$, which express the VIP receptor VPAC2 (135). However, more recent studies indicate that the SCN signals the time of day to GnRH neurons indirectly via AVP fibers projecting to the Kp neurons of the AVPV $(78,89)$.

Anterograde tracing studies show that a number of AVPcontaining axons originating in the SCN make appositions to Kp neurons, whereas very few or no VIP terminals were found apposed to Kp neurons $(87,89)$. Furthermore, AVP is released with a peak coinciding with the onset of the LH surge (136) and AVPV Kp neurons express V1a receptors (87). Interestingly, the AVP input to Kp neurons is sensitive to estradiol since estradiol treatment significantly increases the number of AVP terminal appositions on individual Kp neurons (89) and circadian expression of V1a mRNA is abolished in ovariectomized animals (88). Furthermore, AVP signaling onto Kp neurons is critically dependent on circulating estradiol as AVP no longer activates Kp neurons in ovariectomized mice, an effect that is fully restored by estradiol treatment (90). Altogether, these results are consistent with the hypothesis that $\mathrm{Kp}$ neurons located in the rodent AVPV receive daily information from the SCN via an AVPergic monosynaptic pathway, a signal which is modulated (gated) by circulating estradiol (Figure 1A).
In line with these neuroanatomical observations, earlier physiological experiments pointed to a functional role of AVP in the GnRH/LH surge timing, even though the importance of Kp neurons was not yet known. Inhibition of AVP signaling with a $\mathrm{V} 1 \mathrm{a}$ antagonist resulted in a reduction in the estradiol-induced LH surge (137), while intracerebroventricular infusion of AVP in SCN-lesioned, ovarectomized, and estradiol-treated rats was able to induce an LH surge (138). Furthermore, in co-cultures of POA and SCN, the GnRH surge was coordinated with the rhythm in AVP, but not VIP, and administration of AVP, not VIP, to preoptic explants in the presence of estradiol significantly increased GnRH release, providing further evidence for an important role of AVP in the LH surge generation (139). Finally, a recent study reported that intracerebroventricular administration of AVP in female Syrian hamsters activates Kp neurons similarly in the early or late part of the day, while in the same animals GnRH neurons are activated only late in the day (87). This observation was further confirmed by in vitro electrophysiological recordings of Kp-GFP neurons showing that AVP increases the firing rate of most $\mathrm{Kp}$ neurons during proestrus, independently of the time of day (90). Altogether these findings indicate that AVP activates Kp neurons every day, and the daytime gating of the GnRH/LH surge does not take place through SCN AVP-AVPV Kp signaling but rather downstream at the AVPV Kp-POA GnRH signaling.

A significant role of the SCN-derived VIP output in female reproduction should not be excluded (Figure 1A). Indeed, VIP afferents on $\mathrm{GnRH}$ neurons are sexually dimorphic, with female rats exhibiting higher VIPergic innervation than males (134). Furthermore, central administration of VIP antiserum reduces the LH surge (140), while central infusion of VIP is able to rescue the LH surge in middle-aged female rats (141). Finally, blocking the $\mathrm{VPAC}_{2}$ receptor attenuates $\mathrm{GnRH}$ neuronal cell firing during the afternoon surge in female, estradiol-treated mice (142). A recent study reported that the SCN-derived VIP neurons project to RFRP-3 neurons and central administration of VIP markedly suppresses RFRP-3 cellular activity in the evening, but not the morning, therefore indicating a specific role of VIP on neurons expressing RFRP-3, a neuropeptide thought to participate in the circadian-timed removal of estradiol negative feedback (143).

\section{Other Clocks in the Reproductive System}

It has long been thought that the SCN-driven outputs are the sole source forwarding circadian signals to the female reproductive system. However, a growing body of evidence now suggests that structures and organs that are part of the gonadotropic axis might also play an intrinsic role in the timing of female reproduction.

In mammals, the timing system is now described as a multioscillator hierarchy of coordinated and synchronized cell and tissue clocks (144). The use of Per1-luc transgenic rats (145) and Per2:LUCIFERASE transgenic mice (115), where the Per1 or Per2 promoter drives expression of the luciferase gene, was decisive for the demonstration that non-SCN central structures and peripheral organs can sustain endogenous circadian oscillations. Thus, central structures (e.g., olfactory bulb, ARN, and retrochiasmatic area) and peripheral organs (e.g., liver, lung, heart, and kidney) are able to display endogenous-sustained circadian rhythmicity. The phase and the period of these "peripheral" clocks are tissue 
characteristic and different from those of the "central" clock of the SCN. The strength of their endogenous oscillations is often lesser than that of the SCN since according to tissues (and transgenic mice) the oscillations last from 2 to 20 cycles on average, whereas those of SCN can last several months. The oscillations generated by the peripheral clocks are independent of the SCN activity (they persist in SCN-lesioned animals) but their rhythms appear synchronized by the master clock, which is sometimes referred to as the conductor of the organism's multi-oscillatory network. In the context of such a complex circadian network, recent evidence now suggests that the hypothalamo-pituitary gonadal axis is also a functional multi-oscillatory axis. Indeed, reproductive tissues from hypothalamic Kp and $\mathrm{GnRH}$ neurons down to the ovaries and the uterus display endogenous circadian oscillations of clock genes, as explained below. However, the functional role of these reproductive clocks with regards to the timing of reproduction (ovulation, implantation, and parturition) has yet to be determined.

\section{Kisspeptin Neurons}

Daily and circadian activities of Kp neurons in the AVPV area have been investigated in female rodents because of their strategic position between the integration of SCN-derived AVP input on one hand $(87,89)$ and the triggering of the preovulatory $\mathrm{GnRH} /$ LH surge on the other (19). Additionally, the modulatory effect of circulating estradiol on the daily activity of Kp neurons has also been investigated because of the potent effect of estradiol on Kp synthesis (77). Under high circulating estradiol levels, either in proestrus or in ovariectomized + estradiol-supplemented rodents, Kp neuronal activity (as seen by c-FOS activation) and Kiss $1 \mathrm{mRNA}$ are significantly increased about $3 \mathrm{~h}$ before lights off, thus $2 \mathrm{~h}$ before the LH surge $(9,86-88)$. Furthermore, we recently reported that $\mathrm{Kp}$ immunoreactivity is markedly but transiently decreased at the same time (9). In contrast, in low circulating estradiol conditions, in diestrus or ovariectomized animals, the daily variation in neuronal activity, Kiss 1 mRNA and $\mathrm{Kp}$ immunoreactivty is abolished or strongly dampened (9, $86,88)$. The daily activation of Kp neurons is triggered by the SCN AVP input since central injection of AVP induces c-FOS in Kp neurons and increases Kiss1 mRNA (87). Although AVP is released from the SCN neurons in the afternoon (146), AVP can activate Kp neurons in the morning or in the afternoon, indicating that the daily control of the LH surge is not gated by the AVPV Kp neurons (87). A recent study recording Kp neuron electrical activity confirmed that Kp neuron responsiveness to AVP depends on the concentrations of estradiol (90). Altogether these data indicate that under high circulating estradiol (when oocytes are mature enough to be released), Kp neurons can be activated by the SCN-derived AVP to increase Kp synthesis and release in order to induce GnRH neuronal activation and the downstream $\mathrm{LH}$ surge. In addition to the AVP activation of Kp neurons, we recently reported that these neurons host an intrinsic circadian clock, named Kiss-Clock (9). A preliminary study reported that the clock genes Per1 and Bmal1 are expressed in the rat AVPV, but their cellular localization was not established (88). We further demonstrated that virtually all AVPV Kp neurons express the PER1 protein (Figure 1B) with a daily rhythm both in proestrus and diestrus, but with a phase delay of about $3 \mathrm{~h}$ in diestrus as compared to proestrus (9). Furthermore, we reported that isolated Kp-expressing AVPV explants from PER2:LUCIFERASE mice display endogenous circadian oscillations with a period of $23.2 \mathrm{~h}$ (thus $1 \mathrm{~h}$ shorter than the SCN circadian period of the same mice), confirming the presence of an intrinsic circadian oscillator in AVPV Kp neurons (9) (Figure 1C). Remarkably, the period of this circadian clock is increased by $1 \mathrm{~h}$ in the presence of estradiol in the culture medium (Figure 1C), which is in line with the observed phase difference in PER1 expression according to the estrous stage. In contrast, the period of the SCN clock is not altered by environmental estradiol either in vivo or in vitro (9). The role of this Kiss-Clock has yet to be established. However, according to previous studies one might hypothesize that it could time sensitivity to estradiol since $E R \alpha$ gene expression can be regulated by the BMAL1/CLOCK dimer (147), or it could also impact Kiss1 gene expression since a circadian transcriptional factor, albumin D-site binding protein (Dbp), was reported to trigger Kiss 1 transcription via the D-box (148).

\section{GnRH Neurons}

Because of their pulsatile activity and critical role in timing the LH surge, GnRH neurons were the first in the reproductive system to be reported to express clock genes and display circadian activity. Indeed, all core clock genes (Clock, Bmal1, Per 1/2, and Cry 1/2) are expressed and cycle with a circadian period in both GT1-7 GnRH neuronal cell lines and GnRH neurons (149-152). Disruption of the circadian clock by transient expression of Clock $\Delta 19$ in GT1-7 cells decreases the GnRH pulse frequency, while overexpression of Cry1 in the same cells increases GnRH pulse amplitude (149). The GnRH clock could also regulate the timing of the neuronal sensitivity to upstream inputs. Indeed, the ability of VIP to activate GnRH neurons depends on the time of day and the estradiol environment (153), and the sensitivity of GT1-7 cells to release GnRH upon Kp or VIP treatment is time dependent (151). This time-dependent sensitivity may explain why central infusion of $\mathrm{Kp}$ fails to advance the onset of the $\mathrm{LH}$ surge in either naturally cycling or ovariectomized estradiolsupplemented female rodents $(154,155)$. Finally, the stimulatory and synchronizing effects of $\mathrm{Kp}$ on $\mathrm{GnRH}$ release are reduced in preoptic explants of Bmal1 KO mice (35). Therefore, the circadian clock in GnRH neurons may provide a time-keeping mechanism to appropriately release GnRH under Kp, and possibly VIP, stimulation.

\section{Pituitary Gland and Gonadotroph Cells}

The pituitary, as a whole, was among the first peripheral oscillators found to display strong sustained circadian oscillations with a circadian period of about $23.8 \mathrm{~h}$ in Per1- or PER2-luciferase transgenic rodents $(115,145)$. It was further established that all clock genes expressed a daily rhythm in the whole pituitary but with a different profile according to the estrus stage $(127,156)$. The pituitary gland is made of different cell types, which could host several circadian oscillators with different phases. Expression of all cognate clock genes was identified in the alphaT3-1 gonadotroph cell line (147) and GnRH activation was reported to selectively increase $m$ Per 1 expression in gonadotroph cells (157). 
Furthermore, the gene coding for the GnRH receptor contains non-canonical E-box promoter elements and Bmal1 knockdown in a gonadotrope cell line reduces GnRH receptor mRNA (147). These studies raised the hypothesis that an intrinsic clock in gonadotrophs could directly regulate $\mathrm{GnRH}$ signaling and $\mathrm{LH}$ surge timing. To test this hypothesis, a specific BMAL1 KO disruption was performed in the gonadotrophs (127). The mutated mice still displayed a preovulatory LH surge and estrous cyclicity (although with a significant increase in cycle length variance) and the average time of puberty and fertility performance was not altered. Taken together, these data suggest that the intrinsic clock in gonadotroph cells is dispensable for LH surge regulation but contributes to estrous cycle robustness (127).

\section{Ovaries}

The ovarian circadian clock is very well documented in many mammalian and non-mammalian species and its function has been thoroughly investigated both in vivo and in vitro (158-161). Each cell type of the ovary, including theca cells, granulosa cells, and oocytes have a circadian clock (162). Further analyses reported that clock gene rhythms are only observed in mature granulosa and luteal cells, indicating that these rhythms are activated at a specific stage of follicle development, possibly under the control of FSH acting as a synchronizer of follicular cell activities (163). Ovarian physiology is strongly regulated by gonadotropins, and current studies indicate that LH stimulates various clock genes in the ovaries $(159,164)$. Furthermore, the endogenous rhythm of Per-driven oscillations in isolated ovaries is significantly shifted by $\mathrm{LH}$ and FSH indicating that the ovarian circadian clock is entrained by hormonal signals from the pituitary (160). Recently, a study reported that mice with a conditional $\mathrm{KO}$ of Bmal1 in steroidogenic cells show severe deficits in implantation success and compromised progesterone secretion (165). A previous study demonstrated a circadian rhythm in ovarian sensitivity to LH with a greater ovarian response at night as compared to day, indicating that the ovarian circadian clock may set its responsiveness to the LH surge (161). Finally, various ovarian genes, including those encoding for the $\mathrm{LH}$ receptor and enzymes involved in steroid hormone biosynthesis, display circadian rhythms in granulosa cells and these rhythms are altered following the silencing of Bmal1 expression (163). Altogether, these findings indicate that the clock in the ovary may be involved in the timing of ovulation, steroid hormone synthesis, and follicular growth and differentiation.

\section{Uterus and Oviduct}

Global knockout of the Bmal1 or Clock gene disrupts implantation, increases fetal reabsorption during pregnancy, and leads to a high rate of full-term pregnancy failures $(124,166)$. Early in 2002, clock genes were found to be expressed in the uterus and oviduct of mice (167). Furthermore, the oviduct was reported to display a daily rhythm of several clock genes and clock-controlled gene (168). In the uterus, the presence of sustained endogenous clock oscillations was demonstrated in tissue explants of PER2:LUCIFERASE mice (99). These uterine oscillations were sustained even during pregnancy suggesting that embryos may be submitted to the maternal clock in utero (169). Interestingly, the period of the uterine clock oscillations changes according to the estrous stage and it is decreased when the tissue is incubated with estradiol (99). Additionally, a targeted deletion of Bmal1 in the myometrium indicates a role for myometrial Bmal1 in maintaining normal timing of parturition (170). Although additional studies are required to determine the physiological role of the uterine and oviduct clocks, the data obtained so far suggest that the developing embryo may be subjected to rhythmic changes in the oviduct during transit to the uterus and in the uterus during pregnancy.

\section{Shift-Work Consequences on Reproductive Cycles and Fertility}

\section{Shift Work}

The modern 24-h-functioning society requires that an increasing number of employees work outside of the natural active period, in shifted conditions. According to the International Labor Organization (ILO; 1990), working in shifts is "a method of organization of working time in which workers succeed one another at the workplace so that the establishment can operate longer than the hours of work of individual workers" at different daily and night hours. Under a fixed-shift system, working time can be organized in two or three shifts: the early, late, and/ or nightshifts. Under a rotating-shift system, workers might be assigned to work shifts that vary regularly over time.

Over the last 20 years in United States, almost 27\% of men and $16 \%$ of women experienced shift work (171). In 2012, 15\% of French workers, including 9.3\% women, were working under shift work either occasionally (8\%) or permanently (7.4\%). An increasing number of analyses report that alteration in working schedule is often associated with an increased risk of developing cardiovascular/metabolic/gastrointestinal disorders, some types of cancer, and mental disorders including depression and anxiety (172-174). Hence, in 2007, shift work was reclassified from a possible to a probable human carcinogen (class 2A) by the International Agency for Research on Cancer. A French law passed on December 20, 2014 listed shift work as a risk factor increasing professional arduousness.

Given the importance of the circadian systems in the regulation of female reproduction, and given the fetal exposure to the maternal daily rhythms in temperature, substrates, and hormones, female shift workers may display reproductive alterations, such as an increased risk of irregular menstrual cycles, endometriosis, miscarriage, low birth weight, or pre-term delivery (175-177). Such disturbances may result from altered SCN clock synchronization with rest-activity and feed-fast cycles and/or internal desynchronization amongst peripheral clocks, especially those of the reproductive axis. Indeed, a recent study reported that peripheral clock genes in lymphocytes of shift workers are strongly altered as compared to day workers (178). Additionally, recent animal studies have shown that the functioning of fetal clocks depends on maternal hormones (179) and possibly feeding and activity, then maternal circadian disruption during pregnancy may lead to fetal SCN and peripheral clocks desynchronization. 
In addition to the effect of circadian dysregulation, it should be kept in mind that shift work-related alterations in other daily functions, particularly food intake and sleep, may indirectly impact female reproduction. Thus, obesity, which is often associated with shift work, has a strong impact on reproductive performance (180) and sleep disturbance in prepubertal girls can alter estradiol-dependent pubertal development (181).

\section{Modeling Shift Work in Rodents}

Shift work is a very complex situation and therefore, it is difficult to design animal model conditions that mimic human shift work. A recent review listed four relevant models that use altered timing of food intake, activity, sleep or light exposure, or a combination of several (182).

Very few in vivo animal studies have investigated the alteration of fertility or the LH surge after a shift in the light/dark cycle or a photoperiod change $(6,56,183)$. In one study, female Syrian hamsters were submitted to a 3 -h phase advance or delay (183). When the phase advance was applied between 1 and 3 days before estrous, the LH surge was not fully resynchronized to the new schedule, even after 3 days. However, when hamsters were submitted to a 3-h phase delay, the LH surge was synchronized to the dark onset more rapidly. Similarly, in ovariectomized transgenic GnRH-GFP mice, a dark phase advance led to an advance in the LH surge (56). When the photoperiod length was modified in female hamsters, the timing of the LH surge was shifted in a similar manner to the nocturnal onset of locomotor activity (6).

In mice, exposure to either phase advances or delays at the beginning and throughout pregnancy leads to a significant decrease in pregnancy success (184). Interestingly, an in vitro study analyzed the effect of a 6-h phase advance on endogenous circadian oscillation of the SCN and various peripheral clocks and found that the ovarian clock was not fully resynchronized 6 days after the phase shift (185).

Although these few studies indicate that shifts in light/dark cycle alter the timing of the preovulatory LH surge and the synchrony amongst reproductive clocks, it is obvious that new animal studies have to be developed in order to understand the mechanisms underlying the various effect of shift work on reproduction and fertility in females.

\section{Reproductive Consequence in Women Under Shift Work}

A number of studies have investigated the relationship between fertility and shift work or night work in women working in pharmaceutical industries, hospitals, slaughter houses, and canneries $(175,178,186-200)$. Although human studies are limited in their use for understanding causality and underlying mechanisms of health consequences of shift work, most of the above studies have reported a negative impact of shift work on fertility. However, there is a large heterogeneity among these analyses especially regarding the fertility criteria examined: body temperature curve, menstrual disorders, time to get pregnant, etc. Furthermore, it is important to stress that clinical or biological criteria can be misinterpreted since irregular cycles, as an indicator of the reproductive axis sensibility to shift work, may have no correlation with subfertility and pregnancy capacity (197).
Using body temperature curves to follow menstrual cycles, shift work was found to be associated with higher rates of short cycles and inadequate luteal phases (188). Furthermore, a higher prevalence of menstrual disorders is often found in female shift workers as compared to the non-shift workers. For example, in the most relevant studies including the largest populations, irregular cycles are reported in 12-20\% of shift workers and 7-10\% in nonshift workers $(175,192)$. In a large Danish population $(17,531$ daytime workers and 3,907 shift workers), it was reported that fixed evening and fixed night female workers took longer to get pregnant with adjusted odds ratio around 0.80 , compared to daytime workers, but there was no unequivocal evidence of a causal association between shift work and subfecundity since this reduction may be mediated by pregnancy planning bias or differential options for sexual contacts (187). Only a few studies have examined reproductive hormones with various conclusions. It has been reported that FSH and LH levels are not different between shift and day workers $(190,192)$, but a single measurement of LH without a gynecologic examination and cycle characterization is difficult to interpret. The levels of $17-\beta$-estradiol were found to be significantly increased $(178,201)$ in female shift workers possibly due to a prolonged follicular phase (186). Some studies have reported no significant relationship between shift work and subfertility or dysmenorrhea (196-200). However, among these studies, one has only a few women included with a surprising $35 \%$ of control women displaying irregular cycles (196). Another study reported no significant subfertility in shift-working women 1 year after birth control termination but yet, these women displayed a delay to get pregnant twice as long compared to the day-working group (199).

The pineal hormone melatonin, whose nocturnal production is profoundly affected by shifts in light/dark conditions, has been proposed to display potential anti-estrogenic effects $(202,203)$. Urinary melatonin excretion tends to be lower with a delayed peak of production during shift work $(190,193,201,204)$. The combination of inhibition on melatonin secretion with estradiol mistiming has been proposed to be involved in the hormonerelated cancers observed in night shift workers $(204,205)$.

The conflicting results regarding the negative effect of shift work on female reproduction probably reflect large differences in the shift-work schedules, duration, and age of exposure, with a high number of confounding factors (like stress, fatigue, obesity, etc.) as well as methodological limitations (206, 207). Despite these considerations, cycling disorders should be considered as a sensitivity or intolerance to shift work. Shift work during pregnancy has adverse effects including increased risk of miscarriage (208), although this is somewhat controversial (209). Yet, most authors recommend avoiding shift work during pregnancy.

\section{Conclusion}

Daily and estrogenic regulations of female reproduction allow the timing of ovulation to coincide with optimal reproductive tract functioning (oocyte maturation and receptive reproductive tract), maximal arousal (general activity and sexual motivation), and the best environmental conditions (food resources and stress level). These general coordinations confer maximum adaptive 
advantage to insure the success of this high energy-demanding reproductive function. Although the central role of the master SCN clock in the daily regulation of the LH surge has been well documented, the recent evidence that other peripheral clocks are located all along the gonadotropic axis, from $\mathrm{Kp}$ and $\mathrm{GnRH}$ neurons to the ovaries and uterus, raises the question of their role in the timing of reproduction. The latest findings indicate that these local clocks may optimize circadian cell sensitivity to upstream signals and set appropriate timing of the downstream reproductive responses. Notably, application of phase shifts leads to different rates of clock resynchronization between the SCN and reproductive organs, suggesting internal desynchronization of the reproductive axis, as seen in other functional axes. In our current society, where a significant number of female workers are working night or evening shifts, the delicate timing of organization in the reproductive network can easily be disrupted. While numerous studies have reported negative consequences of shift work on metabolic and cardiovascular functions as well as cancer

\section{References}

1. Hillier SG. Current concepts of the roles of follicle stimulating hormone and luteinizing hormone in folliculogenesis. Hum Reprod (1994) 9:188-91.

2. Norman RL, Blake CA, Sawyer CH. Estrogen-dependent 24-hour periodicity in pituitary LH release in the female hamster. Endocrinology (1973) 93:965-70. doi:10.1210/endo-93-4-965

3. Legan SJ, Karsch FJ. A daily signal for the LH surge in the rat. Endocrinology (1975) 96:57-62. doi:10.1210/endo-96-1-57

4. McElhinny TL, Sisk CL, Holekamp KE, Smale L. A morning surge in plasma luteinizing hormone coincides with elevated Fos expression in gonadotropin-releasing hormone-immunoreactive neurons in the diurnal rodent, Arvicanthis niloticus. Biol Reprod (1999) 61:1115-22. doi:10.1095/ biolreprod61.4.1115

5. Bronson FH, Vom Saal FS. Control of the preovulatory release of luteinizing hormone by steroids in the mouse. Endocrinology (1979) 104:1247-55. doi:10.1210/endo-104-5-1247

6. Moline ML, Albers HE, Todd RB, Moore-Ede MC. Light-dark entrainment of proestrous LH surges and circadian locomotor activity in female hamsters. Horm Behav (1981) 15:451-8. doi:10.1016/0018-506X(81)90009-X

7. Kerdelhué B, Brown S, Lenoir V, Queenan JT, Jones GS, Scholler R, et al. Timing of initiation of the preovulatory luteinizing hormone surge and its relationship with the circadian cortisol rhythm in the human. Neuroendocrinology (2002) 75:158-63. doi:10.1159/000048233

8. Melmed S, Kaiser Ursula B. Gonadotropin hormones. In: The Pituitary. 3rd edn (2010). p. 205-60.

9. Chassard D, Bur I, Poirel V-J, Mendoza J, Simonneaux V. Evidence for a putative circadian Kiss-Clock in the hypothalamic AVPV in female mice. Endocrinology (2015) 156:2999-3011. doi:10.1210/en.2014-1769

10. Bouligand J, Ghervan C, Tello JA, Brailly-Tabard S, Salenave S, Chanson $\mathrm{P}$, et al. Isolated familial hypogonadotropic hypogonadism and a GNRH1 mutation. N Engl J Med (2009) 360:2742-8. doi:10.1056/NEJMoa0900136

11. Chevrier L, Guimiot F, de Roux N. GnRH receptor mutations in isolated gonadotropic deficiency. Mol Cell Endocrinol (2011) 346:21-8. doi:10.1016/j. mce.2011.04.018

12. Crowley WF, McArthur JW. Simulation of the normal menstrual cycle in Kallman's syndrome by pulsatile administration of luteinizing hormone-releasing hormone (LHRH). J Clin Endocrinol Metab (1980) 51:173-5. doi:10.1210/jcem-51-1-173

13. Chryssikopoulos A, Gregoriou O, Papadias C, Loghis C. Gonadotropin ovulation induction and pregnancies in women with Kallmann's syndrome. Gynecol Endocrinol (1998) 12:103-8. doi:10.3109/09513599809024958

14. Knobil E, Plant TM, Wildt L, Belchetz PE, Marshall G. Control of the rhesus monkey menstrual cycle: permissive role of hypothalamic occurrence, there are surprisingly few epidemiologic studies in humans and mechanistic studies in animal models reporting the incidence of shift work on female fertility. Future studies in the field should, therefore, investigate the impact of daily rhythm alterations, as observed under shift-work conditions, jet lag, or sleep disturbance, on reproductive cycle and fertility both in animal models and humans.

\section{Author Contributions}

VS and TB contributed equally to the writing of this review.

\section{Acknowledgments}

Authors are very grateful to Caroline Ancel and Matthew Beymer for their scientific advice and English correction. TB is supported by the Fondation pour la Recherche Médicale for his $\mathrm{PhD}$ research stay (FDM20140630371).

gonadotropin-releasing hormone. Science (1980) 207:1371-3. doi:10.1126/ science. 6766566

15. Lee JH, Miele ME, Hicks DJ, Phillips KK, Trent JM, Weissman BE, et al. KiSS-1, a novel human malignant melanoma metastasis-suppressor gene. J Natl Cancer Inst (1996) 88:1731-7. doi:10.1093/jnci/88.23.1731

16. De Roux N, Genin E, Carel J-C, Matsuda F, Chaussain J-L, Milgrom E. Hypogonadotropic hypogonadism due to loss of function of the KiSS1derived peptide receptor GPR54. Proc Natl Acad Sci US A (2003) 100:10972-6. doi:10.1073/pnas.1834399100

17. Seminara SB, Messager S, Chatzidaki EE, Thresher RR, Acierno JS, Shagoury JK, et al. The GPR54 gene as a regulator of puberty. N Engl J Med (2003) 349:1614-27. doi:10.1056/NEJMoa035322

18. Pinilla L, Aguilar E, Dieguez C, Millar RP, Tena-Sempere M. Kisspeptins and reproduction: physiological roles and regulatory mechanisms. Physiol Rev (2012) 92:1235-316. doi:10.1152/physrev.00037.2010

19. Gottsch ML, Cunningham MJ, Smith JT, Popa SM, Acohido BV, Crowley $\mathrm{WF}$, et al. A role for kisspeptins in the regulation of gonadotropin secretion in the mouse. Endocrinology (2004) 145:4073-7. doi:10.1210/ en.2004-0431

20. Clarkson J, Herbison AE. Postnatal development of kisspeptin neurons in mouse hypothalamus; sexual dimorphism and projections to gonadotropin-releasing hormone neurons. Endocrinology (2006) 147:5817-25. doi:10.1210/en.2006-0787

21. Clarkson J, d'Anglemont de Tassigny X, Colledge WH, Caraty A, Herbison AE. Distribution of kisspeptin neurones in the adult female mouse brain. J Neuroendocrinol (2009) 21:673-82. doi:10.1111/j.1365-2826.2009.01892.x

22. Hoong Yip S, Boehm U, Herbison AE, Campbell RE. Conditional viral tract-tracing delineates the projections of the distinct kisspeptin neuron populations to gonadotropin-releasing hormone $(\mathrm{GnRH})$ neurons in the mouse. Endocrinology (2015) 156:2582-94. doi:10.1210/en.2015-1131

23. Kauffman AS, Gottsch ML, Roa J, Byquist AC, Crown A, Clifton DK, et al. Sexual differentiation of Kiss1 gene expression in the brain of the rat. Endocrinology (2007) 148:1774-83. doi:10.1210/en.2006-1540

24. Smith JT, Popa SM, Clifton DK, Hoffman GE, Steiner RA. Kiss1 neurons in the forebrain as central processors for generating the preovulatory luteinizing hormone surge. J Neurosci (2006) 26:6687-94. doi:10.1523/ JNEUROSCI.1618-06.2006

25. Herbison AE, de Tassigny Xd, Doran J, Colledge WH. Distribution and postnatal development of Gpr54 gene expression in mouse brain and gonadotropin-releasing hormone neurons. Endocrinology (2010) 151:312-21. doi:10.1210/en.2009-0552

26. Simonneaux V, Ancel C, Poirel VJ, Gauer F. Kisspeptins and RFRP-3 act in concert to synchronize rodent reproduction with seasons. Front Neurosci (2013) 7:22. doi:10.3389/fnins.2013.00022 
27. Kotani M, Detheux M, Vandenbogaerde A, Communi D, Vanderwinden JM, Le Poul E, et al. The metastasis suppressor gene KiSS-1 encodes kisspeptins, the natural ligands of the orphan G protein-coupled receptor GPR54. J Biol Chem (2001) 276:34631-6. doi:10.1074/jbc.M104847200

28. Navarro VM, Castellano JM, Fernández-Fernández R, Tovar S, Roa J, Mayen $\mathrm{A}$, et al. Characterization of the potent luteinizing hormone-releasing activity of KiSS-1 peptide, the natural ligand of GPR54. Endocrinology (2005) 146:156-63. doi:10.1210/en.2004-0836

29. Dhillo WS, Chaudhri OB, Patterson M, Thompson EL, Murphy KG, Badman MK, et al. Kisspeptin-54 stimulates the hypothalamic-pituitary gonadal axis in human males. J Clin Endocrinol Metab (2005) 90:6609-15. doi:10.1210/ jc. 2005-1468

30. Plant TM, Ramaswamy S, Dipietro MJ. Repetitive activation of hypothalamic G protein-coupled receptor 54 with intravenous pulses of kisspeptin in the juvenile monkey (Macaca mulatta) elicits a sustained train of gonadotropin-releasing hormone discharges. Endocrinology (2006) 147:1007-13. doi:10.1210/en.2005-1261

31. Tovar S, Vázquez MJ, Navarro VM, Fernández-Fernández R, Castellano JM, Vigo E, et al. Effects of single or repeated intravenous administration of kisspeptin upon dynamic LH secretion in conscious male rats. Endocrinology (2006) 147:2696-704. doi:10.1210/en.2005-1397

32. d'Anglemont de Tassigny X, Fagg LA, Carlton MBL, Colledge WH. Kisspeptin can stimulate gonadotropin-releasing hormone $(\mathrm{GnRH})$ release by a direct action at GnRH nerve terminals. Endocrinology (2008) 149:3926-32. doi:10.1210/en.2007-1487

33. Keen KL, Wegner FH, Bloom SR, Ghatei MA, Terasawa E. An increase in kisspeptin-54 release occurs with the pubertal increase in luteinizing hormone-releasing hormone-1 release in the stalk-median eminence of female rhesus monkeys in vivo. Endocrinology (2008) 149:4151-7. doi:10.1210/ en.2008-0231

34. Plant TM. The role of KiSS-1 in the regulation of puberty in higher primates. Eur J Endocrinol (2006) 155(Suppl):S11-6. doi:10.1530/eje.1.02232

35. Choe HK, Kim H-D, Park SH, Lee H-W, Park J-Y, Seong JY, et al. Synchronous activation of gonadotropin-releasing hormone gene transcription and secretion by pulsatile kisspeptin stimulation. Proc Natl Acad Sci U S A (2013) 110:5677-82. doi:10.1073/pnas.1213594110

36. Topaloglu AK, Tello JA, Kotan LD, Ozbek MN, Yilmaz MB, Erdogan S, et al. Inactivating KISS1 mutation and hypogonadotropic hypogonadism. $N$ Engl $J$ Med (2012) 366:629-35. doi:10.1056/NEJMoal111184

37. d'Anglemont de Tassigny X, Fagg LA, Dixon JPC, Day K, Leitch HG, Hendrick $\mathrm{AG}$, et al. Hypogonadotropic hypogonadism in mice lacking a functional Kiss1 gene. Proc Natl Acad Sci U S A (2007) 104:10714-9. doi:10.1073/ pnas.0704114104

38. Brioude F, Bouligand J, Francou B, Fagart J, Roussel R, Viengchareun S, et al. Two families with normosmic congenital hypogonadotropic hypogonadism and biallelic mutations in KISS1R (KISS1 receptor): clinical evaluation and molecular characterization of a novel mutation. PLoS One (2013) 8:e53896. doi:10.1371/journal.pone.0053896

39. Wahab F, Quinton R, Seminara SB. The kisspeptin signaling pathway and its role in human isolated GnRH deficiency. Mol Cell Endocrinol (2011) 346:29-36. doi:10.1016/j.mce.2011.05.043

40. Petersen SL, Ottem EN, Carpenter CD. Direct and indirect regulation of gonadotropin-releasing hormone neurons by estradiol. Biol Reprod (2003) 69:1771-8. doi:10.1095/biolreprod.103.019745

41. Donoso AO, Seltzer AM, Navarro CE, Cabrera RJ, López FJ, Negro-Vilar A. Regulation of luteinizing hormone-releasing hormone and luteinizing hormone secretion by hypothalamic amino acids. Braz J Med Biol Res (1994) 27:921-32.

42. Ottem EN, Godwin JG, Petersen SL. Glutamatergic signaling through the $\mathrm{N}$-methyl-D-aspartate receptor directly activates medial subpopulations of luteinizing hormone-releasing hormone (LHRH) neurons, but does not appear to mediate the effects of estradiol on LHRH gene expression. Endocrinology (2002) 143:4837-45. doi:10.1210/en.2002-220707

43. Arias P, Jarry H, Leonhardt S, Moguilevsky JA, Wuttke W. Estradiol modulates the LH release response to $\mathrm{N}$-methyl-D-aspartate in adult female rats: studies on hypothalamic luteinizing hormone-releasing hormone and neurotransmitter release. Neuroendocrinology (1993) 57:710-5. doi:10.1159/000126429

44. Watanabe M, Fukuda A, Nabekura J. The role of GABA in the regulation of GnRH neurons. Front Neurosci (2014) 8:387. doi:10.3389/fnins.2014.00387
45. Morello H, Caligaris L, Haymal B, Taleisnik S. Daily variations in the sensitivity of proestrous LH surge in the inhibitory effect of intraventricular injection of 5-HT or GABA in rats. Can J Physiol Pharmacol (1992) 70:447-51. doi:10.1139/y92-057

46. Xu J, Kirigiti MA, Cowley MA, Grove KL, Smith MS. Suppression of basal spontaneous gonadotropin-releasing hormone neuronal activity during lactation: role of inhibitory effects of neuropeptide Y. Endocrinology (2009) 150:333-40. doi:10.1210/en.2008-0962

47. Klenke U, Constantin S, Wray S. Neuropeptide Y directly inhibits neuronal activity in a subpopulation of gonadotropin-releasing hormone-1 neurons via Y1 receptors. Endocrinology (2010) 151:2736-46. doi:10.1210/en.2009-1198

48. Kiyokawa M, Matsuzaki T, Iwasa T, Ogata R, Murakami M, Kinouchi R, et al. Neuropeptide Y mediates orexin A-mediated suppression of pulsatile gonadotropin-releasing hormone secretion in ovariectomized rats. $J$ Med Invest (2011) 58:11-8. doi:10.2152/jmi.58.11

49. Williams WP, Kriegsfeld LJ. Circadian control of neuroendocrine circuits regulating female reproductive function. Front Endocrinol (2012) 3:60. doi:10.3389/fendo.2012.00060

50. Khan AR, Kauffman AS. The role of kisspeptin and RFamide-related peptide-3 neurones in the circadian-timed preovulatory luteinising hormone surge. $J$ Neuroendocrinol (2012) 24:131-43. doi:10.1111/j.1365-2826.2011.02162.x

51. Simonneaux V, Bur I, Ancel C, Ansel L, Klosen P. A kiss for daily and seasonal reproduction. Prog Brain Res (2012) 199:423-37. doi:10.1016/ B978-0-444-59427-3.00024-1

52. Kriegsfeld LJ, Mei DF, Bentley GE, Ubuka T, Mason AO, Inoue K, et al. Identification and characterization of a gonadotropin-inhibitory system in the brains of mammals. Proc Natl Acad Sci U S A (2006) 103:2410-5. doi:10.1073/pnas.0511003103

53. Ubuka T, Inoue K, Fukuda Y, Mizuno T, Ukena K, Kriegsfeld LJ, et al. Identification, expression, and physiological functions of Siberian hamster gonadotropin-inhibitory hormone. Endocrinology (2012) 153:373-85. doi:10.1210/en.2011-1110

54. Gibson EM, Humber SA, Jain S, Williams WP, Zhao S, Bentley GE, et al. Alterations in RFamide-related peptide expression are coordinated with the preovulatory luteinizing hormone surge. Endocrinology (2008) 149:4958-69. doi:10.1210/en.2008-0316

55. León S, García-Galiano D, Ruiz-Pino F, Barroso A, Manfredi-Lozano M, Romero-Ruiz A, et al. Physiological roles of gonadotropin-inhibitory hormone signaling in the control of mammalian reproductive axis: studies in the NPFF1 receptor null mouse. Endocrinology (2014) 155:2953-65. doi:10.1210/en.2014-1030

56. Christian CA, Mobley JL, Moenter SM. Diurnal and estradiol-dependent changes in gonadotropin-releasing hormone neuron firing activity. Proc Natl Acad Sci U S A (2005) 102:15682-7. doi:10.1073/pnas.0504270102

57. White JO, Herschman MJ, Parmar G, Philipson KA, Elder MG, Habib NA, et al. Activated oestrogen receptor in human breast cancer: clinical and biochemical correlates. Br J Surg (1987) 74:588-90. doi:10.1002/ bjs. 1800740715

58. Radovick S, Levine JE, Wolfe A. Estrogenic regulation of the GnRH neuron. Front Endocrinol (2012) 3:52. doi:10.3389/fendo.2012.00052

59. Filardo EJ. Epidermal growth factor receptor (EGFR) transactivation by estrogen via the G-protein-coupled receptor, GPR30: a novel signaling pathway with potential significance for breast cancer. J Steroid Biochem Mol Biol (2002) 80:231-8. doi:10.1016/S0960-0760(01)00190-X

60. Filardo EJ, Quinn JA, Bland KI, Frackelton AR. Estrogen-induced activation of Erk-1 and Erk-2 requires the G protein-coupled receptor homolog, GPR30, and occurs via trans-activation of the epidermal growth factor receptor through release of HB-EGF. Mol Endocrinol (2000) 14:1649-60. doi:10.1210/ mend.14.10.0532

61. Herbison AE, Theodosis DT. Localization of oestrogen receptors in preoptic neurons containing neurotensin but not tyrosine hydroxylase, cholecystokinin or luteinizing hormone-releasing hormone in the male and female rat. Neuroscience (1992) 50:283-98. doi:10.1016/0306-4522(92)90423-Y

62. Dorling AA, Todman MG, Korach KS, Herbison AE. Critical role for estrogen receptor alpha in negative feedback regulation of gonadotropin-releasing hormone mRNA expression in the female mouse. Neuroendocrinology (2003) 78:204-9. doi:10.1159/000073703

63. Wintermantel TM, Campbell RE, Porteous R, Bock D, Gröne H-J, Todman MG, et al. Definition of estrogen receptor pathway critical for estrogen 
positive feedback to gonadotropin-releasing hormone neurons and fertility. Neuron (2006) 52:271-80. doi:10.1016/j.neuron.2006.07.023

64. Hrabovszky E, Shughrue PJ, Merchenthaler I, Hajszán T, Carpenter CD, Liposits Z, et al. Detection of estrogen receptor-beta messenger ribonucleic acid and 125I-estrogen binding sites in luteinizing hormone-releasing hormone neurons of the rat brain. Endocrinology (2000) 141:3506-9. doi:10.1210/endo.141.9.7788

65. Skinner DC, Dufourny L. Oestrogen receptor beta-immunoreactive neurones in the ovine hypothalamus: distribution and colocalisation with gonadotropin-releasing hormone. J Neuroendocrinol (2005) 17:29-39. doi:10.1111/j.1365-2826.2005.01271.x

66. Wolfe A, Wu S. Estrogen receptor- $\beta$ in the gonadotropin-releasing hormone neuron. Semin Reprod Med (2012) 30:23-31. doi:10.1055/s-0031-1299594

67. Noel SD, Keen KL, Baumann DI, Filardo EJ, Terasawa E. Involvement of G protein-coupled receptor 30 (GPR30) in rapid action of estrogen in primate LHRH neurons. Mol Endocrinol (2009) 23:349-59. doi:10.1210/ me.2008-0299

68. Abe H, Terasawa E. Firing pattern and rapid modulation of activity by estrogen in primate luteinizing hormone releasing hormone-1 neurons. Endocrinology (2005) 146:4312-20. doi:10.1210/en.2005-0435

69. Abe H, Keen KL, Terasawa E. Rapid action of estrogens on intracellular calcium oscillations in primate luteinizing hormone-releasing hormone-1 neurons. Endocrinology (2008) 149:1155-62. doi:10.1210/en.2007-0942

70. Chu Z, Andrade J, Shupnik MA, Moenter SM. Differential regulation of gonadotropin-releasing hormone neuron activity and membrane properties by acutely applied estradiol: dependence on dose and estrogen receptor subtype. J Neurosci (2009) 29:5616-27. doi:10.1523/JNEUROSCI.0352-09.2009

71. Abrahám IM, Han S-K, Todman MG, Korach KS, Herbison AE. Estrogen receptor beta mediates rapid estrogen actions on gonadotropin-releasing hormone neurons in vivo. J Neurosci (2003) 23:5771-7.

72. Jacobi JS, Martin C, Nava G, Jeziorski MC, Clapp C, Martínez de la Escalera G. 17-Beta-estradiol directly regulates the expression of adrenergic receptors and kisspeptin/GPR54 system in GT1-7 GnRH neurons. Neuroendocrinology (2007) 86:260-9. doi:10.1159/000107770

73. Tonsfeldt KJ, Goodall CP, Latham KL, Chappell PE. Oestrogen induces rhythmic expression of the Kisspeptin-1 receptor GPR54 in hypothalamic gonadotrophin-releasing hormone-secreting GT1-7 cells. J Neuroendocrinol (2011) 23:823-30. doi:10.1111/j.1365-2826.2011.02188.x

74. Bosch MA, Tonsfeldt KJ, Rønnekleiv OK. mRNA expression of ion channels in GnRH neurons: subtype-specific regulation by $17 \beta$-estradiol. Mol Cell Endocrinol (2013) 367:85-97. doi:10.1016/j.mce.2012.12.021

75. Rønnekleiv OK, Zhang C, Bosch MA, Kelly MJ. Kisspeptin and gonadotropin-releasing hormone neuronal excitability: molecular mechanisms driven by $17 \beta$-estradiol. Neuroendocrinology (2014). doi:10.1159/000370311

76. Cheong RY, Porteous R, Chambon P, Abrahám I, Herbison AE. Effects of neuron-specific estrogen receptor (ER) $\alpha$ and ER $\beta$ deletion on the acute estrogen negative feedback mechanism in adult female mice. Endocrinology (2014) 155:1418-27. doi:10.1210/en.2013-1943

77. Smith JT, Cunningham MJ, Rissman EF, Clifton DK, Steiner RA. Regulation of Kiss1 gene expression in the brain of the female mouse. Endocrinology (2005) 146:3686-92. doi:10.1210/en.2005-0488

78. Revel FG, Saboureau M, Masson-Pévet M, Pévet P, Mikkelsen JD, Simonneaux V. Kisspeptin mediates the photoperiodic control of reproduction in hamsters. Curr Biol (2006) 16:1730-5. doi:10.1016/j.cub.2006.07.025

79. Greives TJ, Mason AO, Scotti M-AL, Levine J, Ketterson ED, Kriegsfeld LJ, et al. Environmental control of kisspeptin: implications for seasonal reproduction. Endocrinology (2007) 148:1158-66. doi:10.1210/en.2006-1249

80. Gottsch ML, Navarro VM, Zhao Z, Glidewell-Kenney C, Weiss J, Jameson JL, et al. Regulation of Kiss1 and dynorphin gene expression in the murine brain by classical and nonclassical estrogen receptor pathways. J Neurosci (2009) 29:9390-5. doi:10.1523/JNEUROSCI.0763-09.2009

81. Ansel L, Bolborea M, Bentsen AH, Klosen P, Mikkelsen JD, Simonneaux V. Differential regulation of kiss1 expression by melatonin and gonadal hormones in male and female Syrian hamsters. J Biol Rhythms (2010) 25:81-91. doi:10.1177/0748730410361918

82. Adachi S, Yamada S, Takatsu Y, Matsui H, Kinoshita M, Takase K, et al. Involvement of anteroventral periventricular metastin/kisspeptin neurons in estrogen positive feedback action on luteinizing hormone release in female rats. J Reprod Dev (2007) 53:367-78. doi:10.1262/jrd.18146
83. Hoffman GE, Le WW, Franceschini I, Caraty A, Advis JP. Expression of fos and in vivo median eminence release of LHRH identifies an active role for preoptic area kisspeptin neurons in synchronized surges of LH and LHRH in the ewe. Endocrinology (2011) 152:214-22. doi:10.1210/en.2010-0066

84. Tomikawa J, Homma T, Tajima S, Shibata T, Inamoto Y, Takase K, et al. Molecular characterization and estrogen regulation of hypothalamic KISS1 gene in the pig. Biol Reprod (2010) 82:313-9. doi:10.1095/ biolreprod.109.079863

85. Huijbregts L, de Roux N. KISS1 is down-regulated by 17beta-estradiol in MDA-MB-231 cells through a nonclassical mechanism and loss of ribonucleic acid polymerase II binding at the proximal promoter. Endocrinology (2010) 151:3764-72. doi:10.1210/en.2010-0260

86. Robertson JL, Clifton DK, de la Iglesia HO, Steiner RA, Kauffman AS. Circadian regulation of Kiss1 neurons: implications for timing the preovulatory gonadotropin-releasing hormone/luteinizing hormone surge. Endocrinology (2009) 150:3664-71. doi:10.1210/en.2009-0247

87. Williams WP, Jarjisian SG, Mikkelsen JD, Kriegsfeld LJ. Circadian control of kisspeptin and a gated GnRH response mediate the preovulatory luteinizing hormone surge. Endocrinology (2011) 152:595-606. doi:10.1210/ en.2010-0943

88. Smarr BL, Gile JJ, de la Iglesia HO. Oestrogen-independent circadian clock gene expression in the anteroventral periventricular nucleus in female rats: possible role as an integrator for circadian and ovarian signals timing the luteinising hormone surge. J Neuroendocrinol (2013) 25:1273-9. doi:10.1111/ jne.12104

89. Vida B, Deli L, Hrabovszky E, Kalamatianos T, Caraty A, Coen CW, et al. Evidence for suprachiasmatic vasopressin neurones innervating kisspeptin neurones in the rostral periventricular area of the mouse brain: regulation by oestrogen. J Neuroendocrinol (2010) 22:1032-9. doi:10.1111/j.1365-2826.2010.02045.x

90. Piet R, Fraissenon A, Boehm U, Herbison AE. Estrogen permits vasopressin signaling in preoptic kisspeptin neurons in the female mouse. J Neurosci (2015) 35:6881-92. doi:10.1523/JNEUROSCI.4587-14.2015

91. Morin LP, Fitzgerald KM, Zucker I. Estradiol shortens the period of hamster circadian rhythms. Science (1977) 196:305-7. doi:10.1126/science.557840

92. Takahashi JS, Menaker M. Interaction of estradiol and progesterone: effects on circadian locomotor rhythm of female golden hamsters. Am J Physiol (1980) 239:R497-504.

93. Albers HE. Gonadal hormones organize and modulate the circadian system of the rat. Am J Physiol (1981) 241:R62-6.

94. Bailey M, Silver R. Sex differences in circadian timing systems: implications for disease. Front Neuroendocrinol (2014) 35:111-39. doi:10.1016/j. yfrne.2013.11.003

95. Kopp C, Ressel V, Wigger E, Tobler I. Influence of estrus cycle and ageing on activity patterns in two inbred mouse strains. Behav Brain Res (2006) 167:165-74. doi:10.1016/j.bbr.2005.09.001

96. Royston SE, Yasui N, Kondilis AG, Lord SV, Katzenellenbogen JA, Mahoney MM. ESR1 and ESR2 differentially regulate daily and circadian activity rhythms in female mice. Endocrinology (2014) 155:2613-23. doi:10.1210/ en.2014-1101

97. Nakamura TJ, Shinohara K, Funabashi T, Kimura F. Effect of estrogen on the expression of Cryl and Cry2 mRNAs in the suprachiasmatic nucleus of female rats. Neurosci Res (2001) 41:251-5. doi:10.1016/S0168-0102(01)00285-1

98. Fatehi M, Fatehi-Hassanabad Z. Effects of 17beta-estradiol on neuronal cell excitability and neurotransmission in the suprachiasmatic nucleus of rat. Neuropsychopharmacology (2008) 33:1354-64. doi:10.1038/ sj.npp. 1301523

99. Nakamura TJ, Sellix MT, Menaker M, Block GD. Estrogen directly modulates circadian rhythms of PER2 expression in the uterus. Am J Physiol Endocrinol Metab (2008) 295:E1025-31. doi:10.1152/ajpendo.90392.2008

100. Ogawa S, Chan J, Gustafsson J-A, Korach KS, Pfaff DW. Estrogen increases locomotor activity in mice through estrogen receptor alpha: specificity for the type of activity. Endocrinology (2003) 144:230-9. doi:10.1210/ en.2002-220519

101. Krizo JA, Mintz EM. Sex differences in behavioral circadian rhythms in laboratory rodents. Front Endocrinol (2014) 5:234. doi:10.3389/fendo.2014.00234

102. Clarke IJ, Cummins JT. Direct pituitary effects of estrogen and progesterone on gonadotropin secretion in the ovariectomized ewe. Neuroendocrinology (1984) 39:267-74. doi:10.1159/000123990 
103. Friend KE, Chiou YK, Lopes MB, Laws ER, Hughes KM, Shupnik MA. Estrogen receptor expression in human pituitary: correlation with immunohistochemistry in normal tissue, and immunohistochemistry and morphology in macroadenomas. J Clin Endocrinol Metab (1994) 78:1497-504. doi:10.1210/jcem.78.6.7515390

104. Scully KM, Gleiberman AS, Lindzey J, Lubahn DB, Korach KS, Rosenfeld MG. Role of estrogen receptor-alpha in the anterior pituitary gland. Mol Endocrinol (1997) 11:674-81. doi:10.1210/mend.11.6.0019

105. Clarke IJ, Cummins JT, Crowder ME, Nett TM. Long-term negative feedback effects of oestrogen and progesterone on the pituitary gland of the longterm ovariectomized ewe. J Endocrinol (1989) 120:207-14. doi:10.1677/ joe.0.1200207

106. Shaw ND, Histed SN, Srouji SS, Yang J, Lee H, Hall JE. Estrogen negative feedback on gonadotropin secretion: evidence for a direct pituitary effect in women. J Clin Endocrinol Metab (2010) 95:1955-61. doi:10.1210/ jc.2009-2108

107. Singh SP, Wolfe A, Ng Y, DiVall SA, Buggs C, Levine JE, et al. Impaired estrogen feedback and infertility in female mice with pituitary-specific deletion of estrogen receptor alpha (ESR1). Biol Reprod (2009) 81:488-96. doi:10.1095/ biolreprod.108.075259

108. Richard N, Galmiche G, Corvaisier S, Caraty A, Kottler M-L. KiSS-1 and GPR54 genes are co-expressed in rat gonadotrophs and differentially regulated in vivo by oestradiol and gonadotrophin-releasing hormone. J Neuroendocrinol (2008) 20:381-93. doi:10.1111/j.1365-2826.2008.01653.x

109. Wang H, Masironi B, Eriksson H, Sahlin L. A comparative study of estrogen receptors alpha and beta in the rat uterus. Biol Reprod (1999) 61:955-64. doi:10.1095/biolreprod61.4.955

110. Hamilton KJ, Arao Y, Korach KS. Estrogen hormone physiology: reproductive findings from estrogen receptor mutant mice. Reprod Biol (2014) 14:3-8. doi:10.1016/j.repbio.2013.12.002

111. Lehman MN, Silver R, Gladstone WR, Kahn RM, Gibson M, Bittman EL. Circadian rhythmicity restored by neural transplant. Immunocytochemical characterization of the graft and its integration with the host brain. J Neurosci (1987) 7:1626-38.

112. Ralph MR, Foster RG, Davis FC, Menaker M. Transplanted suprachiasmatic nucleus determines circadian period. Science (1990) 247:975-8. doi:10.1126/ science. 2305266

113. Lowrey PL, Takahashi JS. Genetics of circadian rhythms in Mammalian model organisms. Adv Genet (2011) 74:175-230. doi:10.1016/ B978-0-12-387690-4.00006-4

114. Albrecht U, Eichele G. The mammalian circadian clock. Curr Opin Genet Dev (2003) 13:271-7. doi:10.1016/S0959-437X(03)00055-8

115. Yoo S-H, Yamazaki S, Lowrey PL, Shimomura K, Ko CH, Buhr ED, et al. PERIOD2:LUCIFERASE real-time reporting of circadian dynamics reveals persistent circadian oscillations in mouse peripheral tissues. Proc Natl Acad Sci U S A (2004) 101:5339-46. doi:10.1073/pnas.0308709101

116. Yoo S-H, Ko CH, Lowrey PL, Buhr ED, Song E, Chang S, et al. A noncanonical E-box enhancer drives mouse Period2 circadian oscillations in vivo. Proc Natl Acad Sci U S A (2005) 102:2608-13. doi:10.1073/pnas.0409763102

117. Berson DM, Dunn FA, Takao M. Phototransduction by retinal ganglion cells that set the circadian clock. Science (2002) 295:1070-3. doi:10.1126/ science. 1067262

118. Provencio I, Rollag MD, Castrucci AM. Photoreceptive net in the mammalian retina. This mesh of cells may explain how some blind mice can still tell day from night. Nature (2002) 415:493. doi:10.1038/415493a

119. Jin X, Shearman LP, Weaver DR, Zylka MJ, de Vries GJ, Reppert SM. A molecular mechanism regulating rhythmic output from the suprachiasmatic circadian clock. Cell (1999) 96:57-68. doi:10.1016/ S0092-8674(00)80959-9

120. Miller G. Neurobiology. Despite mutated gene, mouse circadian clock keeps on ticking. Science (2006) 312:673. doi:10.1126/science.312.5774.673

121. Brown-Grant K, Raisman G. Abnormalities in reproductive function associated with the destruction of the suprachiasmatic nuclei in female rats. $\operatorname{Proc} R$ Soc Lond B Biol Sci (1977) 198:279-96. doi:10.1098/rspb.1977.0098

122. Wiegand SJ, Terasawa E, Bridson WE, Goy RW. Effects of discrete lesions of preoptic and suprachiasmatic structures in the female rat. Alterations in the feedback regulation of gonadotropin secretion. Neuroendocrinology (1980) 31:147-57. doi:10.1159/000123066
123. Van der Horst GT, Muijtjens M, Kobayashi K, Takano R, Kanno S, Takao M, et al. Mammalian Cry1 and Cry2 are essential for maintenance of circadian rhythms. Nature (1999) 398:627-30. doi:10.1038/19323

124. Miller BH, Olson SL, Turek FW, Levine JE, Horton TH, Takahashi JS. Circadian clock mutation disrupts estrous cyclicity and maintenance of pregnancy. Curr Biol (2004) 14:1367-73. doi:10.1016/j.cub.2004.07.055

125. Dolatshad H, Campbell EA, O’Hara L, Maywood ES, Hastings MH, Johnson MH. Developmental and reproductive performance in circadian mutant mice. Hum Reprod (2006) 21:68-79. doi:10.1093/humrep/dei313

126. Ratajczak CK, Boehle KL, Muglia LJ. Impaired steroidogenesis and implantation failure in Bmal1-/- mice. Endocrinology (2009) 150:1879-85. doi:10.1210/en.2008-1021

127. Chu A, Zhu L, Blum ID, Mai O, Leliavski A, Fahrenkrug J, et al. Global but not gonadotrope-specific disruption of Bmall abolishes the luteinizing hormone surge without affecting ovulation. Endocrinology (2013) 154:2924-35. doi:10.1210/en.2013-1080

128. Kovanen L, Saarikoski ST, Aromaa A, Lönnqvist J, Partonen T. ARNTL (BMAL1) and NPAS2 gene variants contribute to fertility and seasonality. PLoS One (2010) 5:e10007. doi:10.1371/journal.pone.0010007

129. Pilorz V, Steinlechner S. Low reproductive success in Per1 and Per2 mutant mouse females due to accelerated ageing? Reproduction (2008) 135:559-68. doi:10.1530/REP-07-0434

130. Miller BH, Takahashi JS. Central circadian control of female reproductive function. Front Endocrinol (2013) 4:195. doi:10.3389/fendo.2013.00195

131. Legan SJ, Coon GA, Karsch FJ. Role of estrogen as initiator of daily LH surges in the ovariectomized rat. Endocrinology (1975) 96:50-6. doi:10.1210/ endo-96-1-50

132. Silver R, LeSauter J, Tresco PA, Lehman MN. A diffusible coupling signal from the transplanted suprachiasmatic nucleus controlling circadian locomotor rhythms. Nature (1996) 382:810-3. doi:10.1038/382810a0

133. Van der Beek EM, Horvath TL, Wiegant VM, Van den Hurk R, Buijs RM. Evidence for a direct neuronal pathway from the suprachiasmatic nucleus to the gonadotropin-releasing hormone system: combined tracing and light and electron microscopic immunocytochemical studies. J Comp Neurol (1997) 384:569-79. doi:10.1002/ (SICI)1096-9861(19970811)384:4<569::AID-CNE6>3.0.CO;2-0

134. Horvath TL, Cela V, van der Beek EM. Gender-specific apposition between vasoactive intestinal peptide-containing axons and gonadotrophin-releasing hormone-producing neurons in the rat. Brain Res (1998) 795:277-81. doi:10.1016/S0006-8993(98)00208-X

135. Smith MJ, Jiennes L, Wise PM. Localization of the VIP2 receptor protein on GnRH neurons in the female rat. Endocrinology (2000) 141:4317-20. doi:10.1210/endo.141.11.7876

136. Kalsbeek A, Buijs RM, Engelmann M, WotjakCT, Landgraf R. In vivo measurement of a diurnal variation in vasopressin release in the rat suprachiasmatic nucleus. Brain Res (1995) 682:75-82. doi:10.1016/0006-8993(95)00324-J

137. Funabashi T, Aiba S, Sano A, Shinohara K, Kimura F. Intracerebroventricular injection of arginine-vasopressin V1 receptor antagonist attenuates the surge of luteinizing hormone and prolactin secretion in proestrous rats. Neurosci Lett (1999) 260:37-40. doi:10.1016/S0304-3940(98)00940-9

138. Palm IF, Van Der Beek EM, Wiegant VM, Buijs RM, Kalsbeek A. Vasopressin induces a luteinizing hormone surge in ovariectomized, estradiol-treated rats with lesions of the suprachiasmatic nucleus. Neuroscience (1999) 93:659-66. doi:10.1016/S0306-4522(99)00106-2

139. Funabashi T, Shinohara K, Mitsushima D, Kimura F. Gonadotropin-releasing hormone exhibits circadian rhythm in phase with arginine-vasopressin in co-cultures of the female rat preoptic area and suprachiasmatic nucleus. $J$ Neuroendocrinol (2000) 12:521-8. doi:10.1046/j.1365-2826.2000.00481.x

140. Van der Beek EM, Swarts HJ, Wiegant VM. Central administration of antiserum to vasoactive intestinal peptide delays and reduces luteinizing hormone and prolactin surges in ovariectomized, estrogen-treated rats. Neuroendocrinology (1999) 69:227-37. doi:10.1159/000054423

141. Sun Y, Shu J, Kyei K, Neal-Perry GS. Intracerebroventricular infusion of vasoactive intestinal Peptide rescues the luteinizing hormone surge in middle-aged female rats. Front Endocrinol (2012) 3:24. doi:10.3389/ fendo.2012.00024

142. Christian CA, Moenter SM. Critical roles for fast synaptic transmission in mediating estradiol negative and positive feedback in the neural control of ovulation. Endocrinology (2008) 149:5500-8. doi:10.1210/en.2008-0453 
143. Russo KA, La JL, Stephens SBZ, Poling MC, Padgaonkar NA, Jennings $\mathrm{KJ}$, et al. Circadian control of the female reproductive axis through gated responsiveness of the RFRP-3 system to VIP signaling. Endocrinology (2015) 156:2608-18. doi:10.1210/en.2014-1762

144. Menaker M, Murphy ZC, Sellix MT. Central control of peripheral circadian oscillators. Curr Opin Neurobiol (2013) 23:741-6. doi:10.1016/j. conb.2013.03.003

145. Abe M, Herzog ED, Yamazaki S, Straume M, Tei H, Sakaki Y, et al. Circadian rhythms in isolated brain regions. J Neurosci (2002) 22:350-6.

146. Kalsbeek A, Fliers E, Hofman MA, Swaab DF, Buijs RM. Vasopressin and the output of the hypothalamic biological clock. J Neuroendocrinol (2010) 22:362-72. doi:10.1111/j.1365-2826.2010.01956.x

147. Resuehr D, Wildemann U, Sikes H, Olcese J. E-box regulation of gonadotropin-releasing hormone $(\mathrm{GnRH})$ receptor expression in immortalized gonadotrope cells. Mol Cell Endocrinol (2007) 278:36-43. doi:10.1016/j. mce.2007.08.008

148. Xu Z, Kaga S, Tsubomizu J, Fujisaki J, Mochiduki A, Sakai T, et al. Circadian transcriptional factor DBP regulates expression of Kiss 1 in the anteroventral periventricular nucleus. Mol Cell Endocrinol (2011) 339:90-7. doi:10.1016/j. mce.2011.03.020

149. Chappell PE, White RS, Mellon PL. Circadian gene expression regulates pulsatile gonadotropin-releasing hormone $(\mathrm{GnRH})$ secretory patterns in the hypothalamic GnRH-secreting GT1-7 cell line. J Neurosci (2003) 23:11202-13.

150. Gillespie JMA, Chan BPK, Roy D, Cai F, Belsham DD. Expression of circadian rhythm genes in gonadotropin-releasing hormone-secreting GT1-7 neurons. Endocrinology (2003) 144:5285-92. doi:10.1210/en.2003-0802

151. Zhao S, Kriegsfeld LJ. Daily changes in GT1-7 cell sensitivity to GnRH secretagogues that trigger ovulation. Neuroendocrinology (2009) 89:448-57. doi:10.1159/000192370

152. Hickok JR, Tischkau SA. In vivo circadian rhythms in gonadotropin-releasing hormone neurons. Neuroendocrinology (2010) 91:110-20. doi: $10.1159 / 000243163$

153. Christian CA, Moenter SM. Estradiol induces diurnal shifts in GABA transmission to gonadotropin-releasing hormone neurons to provide a neural signal for ovulation. J Neurosci (2007) 27:1913-21. doi:10.1523/ JNEUROSCI.4738-06.2007

154. Roa J, Castellano JM, Navarro VM, Handelsman DJ, Pinilla L, TenaSempere M. Kisspeptins and the control of gonadotropin secretion in male and female rodents. Peptides (2009) 30:57-66. doi:10.1016/j. peptides.2008.08.009

155. Neal-Perry G, Lebesgue D, Lederman M, Shu J, Zeevalk GD, Etgen AM. The excitatory peptide kisspeptin restores the luteinizing hormone surge and modulates amino acid neurotransmission in the medial preoptic area of middle-aged rats. Endocrinology (2009) 150:3699-708. doi:10.1210/ en.2008-1667

156. Bur IM, Cohen-Solal AM, Carmignac D, Abecassis P-Y, Chauvet N, Martin AO, et al. The circadian clock components CRY1 and CRY2 are necessary to sustain sex dimorphism in mouse liver metabolism. J Biol Chem (2009) 284:9066-73. doi:10.1074/jbc.M808360200

157. Olcese J, Sikes HE, Resuehr D. Induction of PER1 mRNA expression in immortalized gonadotropes by gonadotropin-releasing hormone ( $\mathrm{GnRH})$ : involvement of protein kinase $\mathrm{C}$ and MAP kinase signaling. Chronobiol Int (2006) 23:143-50. doi:10.1080/07420520500521996

158. Fahrenkrug J, Georg B, Hannibal J, Hindersson P, Gräs S. Diurnal rhythmicity of the clock genes Per1 and Per2 in the rat ovary. Endocrinology (2006) 147:3769-76. doi:10.1210/en.2006-0305

159. Karman BN, Tischkau SA. Circadian clock gene expression in the ovary: effects of luteinizing hormone. Biol Reprod (2006) 75:624-32. doi:10.1095/ biolreprod.106.050732

160. Yoshikawa T, Sellix M, Pezuk P, Menaker M. Timing of the ovarian circadian clock is regulated by gonadotropins. Endocrinology (2009) 150:4338-47. doi:10.1210/en.2008-1280

161. Sellix MT. Clocks underneath: the role of peripheral clocks in the timing of female reproductive physiology. Front Endocrinol (2013) 4:91. doi:10.3389/ fendo.2013.00091

162. Sellix MT. Circadian clock function in the mammalian ovary. J Biol Rhythms (2015) 30:7-19. doi:10.1177/0748730414554222
163. Chen H, Zhao L, Kumazawa M, Yamauchi N, Shigeyoshi Y, Hashimoto S, et al. Downregulation of core clock gene Bmall attenuates expression of progesterone and prostaglandin biosynthesis-related genes in rat luteinizing granulosa cells. Am J Physiol Cell Physiol (2013) 304:C1131-40. doi:10.1152/ ajpcell.00008.2013

164. He P-J, Hirata M, Yamauchi N, Hashimoto S, Hattori M-A. Gonadotropic regulation of circadian clockwork in rat granulosa cells. Mol Cell Biochem (2007) 302:111-8. doi:10.1007/s11010-007-9432-7

165. Liu Y, Johnson BP, Shen AL, Wallisser JA, Krentz KJ, Moran SM, et al. Loss of BMAL1 in ovarian steroidogenic cells results in implantation failure in female mice. Proc Natl Acad Sci U S A (2014) 111:14295-300. doi:10.1073/ pnas. 1209249111

166. Ratajczak CK, Herzog ED, Muglia LJ. Clock gene expression in gravid uterus and extra-embryonic tissues during late gestation in the mouse. Reprod Fertil Dev (2010) 22:743-50. doi:10.1071/RD09243

167. Johnson MH, Lim A, Fernando D, Day ML. Circadian clockwork genes are expressed in the reproductive tract and conceptus of the early pregnant mouse. Reprod Biomed Online (2002) 4:140-5. doi:10.1016/S1472-6483(10)61931-1

168. Kennaway DJ, Varcoe TJ, Mau VJ. Rhythmic expression of clock and clock-controlled genes in the rat oviduct. Mol Hum Reprod (2003) 9:503-7. doi:10.1093/molehr/gag067

169. Akiyama S, Ohta H, Watanabe S, Moriya T, Hariu A, Nakahata N, et al. The uterus sustains stable biological clock during pregnancy. Tohoku J Exp Med (2010) 221:287-98. doi:10.1620/tjem.221.287

170. Ratajczak CK, Asada M, Allen GC, McMahon DG, Muglia LM, Smith D, et al. Generation of myometrium-specific Bmall knockout mice for parturition analysis. Reprod Fertil Dev (2012) 24:759-67. doi:10.1071/RD11164

171. Pati A, Chandrawanshi A, Reinberg A. Shift work: consequences and management. Curr Sci (2001) 81:32-52.

172. Boivin DB, Tremblay GM, James FO. Working on atypical schedules. Sleep Med (2007) 8:578-89. doi:10.1016/j.sleep.2007.03.015

173. Chen J-D, Lin Y-C, Hsiao S-T. Obesity and high blood pressure of 12-hour night shift female clean-room workers. Chronobiol Int (2010) 27:334-44. doi:10.3109/07420520903502242

174. Matheson A, O'Brien L, Reid J-A. The impact of shiftwork on health: a literature review. J Clin Nurs (2014) 23:3309-20. doi:10.1111/jocn.12524

175. Lawson CC, Whelan EA, Lividoti Hibert EN, Spiegelman D, Schernhammer ES, Rich-Edwards JW. Rotating shift work and menstrual cycle characteristics. Epidemiology (2011) 22:305-12. doi:10.1097/EDE.0b013e3182130016

176. Rocheleau CM, Lawson CC, Whelan EA, Rich-Edwards JW. Shift work and adverse pregnancy outcomes: comments on a recent meta-analysis. BJOG (2012) 119:378. doi:10.1111/j.1471-0528.2011.03211.x author reply 379-80,

177. Gamble KL, Resuehr D, Johnson CH. Shift work and circadian dysregulation of reproduction. Front Endocrinol (2013) 4:92. doi:10.3389/fendo.2013.00092

178. Bracci M, Manzella N, Copertaro A, Staffolani S, Strafella E, Barbaresi M, et al. Rotating-shift nurses after a day off: peripheral clock gene expression, urinary melatonin, and serum 17- $\beta$-estradiol levels. Scand J Work Environ Health (2014) 40:295-304. doi:10.5271/sjweh.3414

179. Torres-Farfan C, Mendez N, Abarzua-Catalan L, Vilches N, Valenzuela GJ, Seron-Ferre M. A circadian clock entrained by melatonin is ticking in the rat fetal adrenal. Endocrinology (2011) 152:1891-900. doi:10.1210/en.2010-1260

180. Klenov VE, Jungheim ES. Obesity and reproductive function: a review of the evidence. Curr Opin Obstet Gynecol (2014) 26:455-60. doi:10.1097/ GCO.0000000000000113

181. Shaw ND, Goodwin JL, Silva GE, Hall JE, Quan SF, Malhotra A. Obstructive sleep apnea (OSA) in preadolescent girls is associated with delayed breast development compared to girls without OSA. J Clin Sleep Med (2013) 9:813-8. doi:10.5664/jcsm.2928

182. Opperhuizen A-L, van Kerkhof LWM, Proper KI, Rodenburg W, Kalsbeek A. Rodent models to study the metabolic effects of shiftwork in humans. Front Pharmacol (2015) 6:50. doi:10.3389/fphar.2015.00050

183. Moline ML, Albers HE. Response of circadian locomotor activity and the proestrous luteinizing hormone surge to phase shifts of the light-dark cycle in the hamster. Physiol Behav (1988) 43:435-40. doi:10.1016/0031-9384(88)90116-3

184. Summa KC, Vitaterna MH, Turek FW. Environmental perturbation of the circadian clock disrupts pregnancy in the mouse. PLoS One (2012) 7:e37668. doi:10.1371/journal.pone.0037668 
185. Yamazaki S, Numano R, Abe M, Hida A, Takahashi R, Ueda M, et al. Resetting central and peripheral circadian oscillators in transgenic rats. Science (2000) 288:682-5. doi:10.1126/science.288.5466.682

186. Lohstroh PN, Chen J, Ba J, Ryan LM, Xu X, Overstreet JW, et al. Bone resorption is affected by follicular phase length in female rotating shift workers. Environ Health Perspect (2003) 111:618-22. doi:10.1289/ehp.5878

187. Zhu JL, Hjollund NH, Boggild H, Olsen J. Shift work and subfecundity: a causal link or an artefact? Occup Environ Med (2003) 60:E12. doi:10.1136/ oem.60.9.e12

188. Hatch MC, Figa-Talamanca I, Salerno S. Work stress and menstrual patterns among American and Italian nurses. Scand J Work Environ Health (1999) 25:144-50. doi:10.5271/sjweh.417

189. Ahlborg G, Axelsson G, Bodin L. Shift work, nitrous oxide exposure and subfertility among Swedish midwives. Int J Epidemiol (1996) 25:783-90. doi:10.1093/ije/25.4.783

190. Miyauchi F, Nanjo K, Otsuka K. Effects of night shift on plasma concentrations of melatonin, LH, FSH and prolactin, and menstrual irregularity. Sangyo Igaku (1992) 34:545-50. doi:10.1539/joh1959.34.545

191. Messing K, Saurel-Cubizolles MJ, Bourgine M, Kaminski M. Menstrual-cycle characteristics and work conditions of workers in poultry slaughterhouses and canneries. Scand J Work Environ Health (1992) 18:302-9. doi:10.5271/ sjweh. 1572

192. Attarchi M, Darkhi H, Khodarahmian M, Dolati M, Kashanian M, Ghaffari M, et al. Characteristics of menstrual cycle in shift workers. Glob J Health Sci (2013) 5:163-72. doi:10.5539/gjhs.v5n3p163

193. Davis S, Mirick DK, Chen C, Stanczyk FZ. Night shift work and hormone levels in women. Cancer Epidemiol Biomarkers Prev (2012) 21:609-18. doi:10.1158/1055-9965.EPI-11-1128

194. Wan G-H, Chung F-F. Working conditions associated with ovarian cycle in a medical center nurses: a Taiwan study. Jpn J Nurs Sci (2012) 9:112-8. doi:10.1111/j.1742-7924.2011.00191.x

195. Labyak S, Lava S, Turek F, Zee P. Effects of shiftwork on sleep and menstrual function in nurses. Health Care Women Int (2002) 23:703-14. doi:10.1080/07399330290107449

196. Chung F-F, Yao C-CC, Wan G-H. The associations between menstrual function and life style/working conditions among nurses in Taiwan. J Occup Health (2005) 47:149-56. doi:10.1539/joh.47.149

197. Stocker LJ, Macklon NS, Cheong YC, Bewley SJ. Influence of shift work on early reproductive outcomes: a systematic review and meta-analysis. Obstet Gynecol (2014) 124:99-110. doi:10.1097/AOG.0000000000000321

198. Olsen J. Cigarette smoking, tea and coffee drinking, and subfecundity. Am J Epidemiol (1991) 133:734-9.

199. Spinelli A, Figà-Talamanca I, Osborn J. Time to pregnancy and occupation in a group of Italian women. Int J Epidemiol (1997) 26:601-9. doi:10.1093/ ije/26.3.601
200. Tuntiseranee P, Olsen J, Geater A, Kor-anantakul O. Are long working hours and shiftwork risk factors for subfecundity? A study among couples from southern Thailand. Occup Environ Med (1998) 55:99-105. doi:10.1136/ oem.55.2.99

201. Gómez-Acebo I, Dierssen-Sotos T, Papantoniou K, García-Unzueta MT, Santos-Benito MF, Llorca J. Association between exposure to rotating night shift versus day shift using levels of 6-sulfatoxymelatonin and cortisol and other sex hormones in women. Chronobiol Int (2014) 32:128-35. doi:10.310 9/07420528.2014.958494

202. Alvarez-García V, González A, Martínez-Campa C, Alonso-González C, Cos S. Melatonin modulates aromatase activity and expression in endothelial cells. Oncol Rep (2013) 29:2058-64. doi:10.3892/or.2013.2314

203. Cos S, Martínez-Campa C, Mediavilla MD, Sánchez-Barceló EJ. Melatonin modulates aromatase activity in MCF-7 human breast cancer cells. J Pineal Res (2005) 38:136-42. doi:10.1111/j.1600-079X.2004.00186.x

204. Papantoniou K, Pozo OJ, Espinosa A, Marcos J, Castaño-Vinyals G, Basagaña $\mathrm{X}$, et al. Increased and mistimed sex hormone production in night shift workers. Cancer Epidemiol Biomarkers Prev (2015) 24:854-63. doi:10.1158/10559965.EPI-14-1271

205. Hill SM, Belancio VP, Dauchy RT, Xiang S, Brimer S, Mao L, et al. Melatonin: an inhibitor of breast cancer. Endocr Relat Cancer (2015) 22:R183-204. doi:10.1530/ERC-15-0030

206. Gold EB, Tomich E. Occupational hazards to fertility and pregnancy outcome. Occup Med (1994) 9:435-69.

207. Weinberg CR, Baird DD, Wilcox AJ. Sources of bias in studies of time to pregnancy. Stat Med (1994) 13:671-81. doi:10.1002/sim.4780130528

208. Axelsson G, Ahlborg G, Bodin L. Shift work, nitrous oxide exposure, and spontaneous abortion among Swedish midwives. Occup Environ Med (1996) 53:374-8. doi:10.1136/oem.53.6.374

209. Bonde JP, Jørgensen KT, Bonzini M, Palmer KT. Miscarriage and occupational activity: a systematic review and meta-analysis regarding shift work, working hours, lifting, standing, and physical workload. Scand J Work Environ Health (2013) 39:325-34. doi:10.5271/sjweh.3337

Conflict of Interest Statement: The authors declare that the research was conducted in the absence of any commercial or financial relationships that could be construed as a potential conflict of interest.

Copyright (c) 2015 Simonneaux and Bahougne. This is an open-access article distributed under the terms of the Creative Commons Attribution License (CC BY). The use, distribution or reproduction in other forums is permitted, provided the original author(s) or licensor are credited and that the original publication in this journal is cited, in accordance with accepted academic practice. No use, distribution or reproduction is permitted which does not comply with these terms. 